\title{
Development of green/red-absorbing chromophores based on a coumarin scaffold useful as caging groups
}

\author{
Albert Gandioso, ${ }^{\dagger}$ Sara Contreras,${ }^{\dagger}$ Ivanna Melnyk,${ }^{\dagger}$ Javier Oliva,${ }^{\dagger}$ Santi Nonell,${ }^{\S}$ \\ Dolores Velasco, ${ }^{\dagger}, \grave{\dagger}$ Jaume García-Amorós, ${ }^{\dagger}$ Vicente Marchán*,†
}

†Secció de Química Orgànica, Departament de Química Inorgànica i Orgànica, IBUB

Universitat de Barcelona Martí i Franquès 1-11 E-08028 Barcelona (Spain)

E-mail: vmarchan@ub.edu

${ }^{\sharp}$ Institut de Nanociència i Nanotecnologia (IN2UB). Universitat de Barcelona. E-08028

Barcelona (Spain)

§ Institut Químic de Sarrià, Universitat Ramon Llull, E-08017 Barcelona (Spain)

\section{TOC ABSTRACT GRAPHIC}
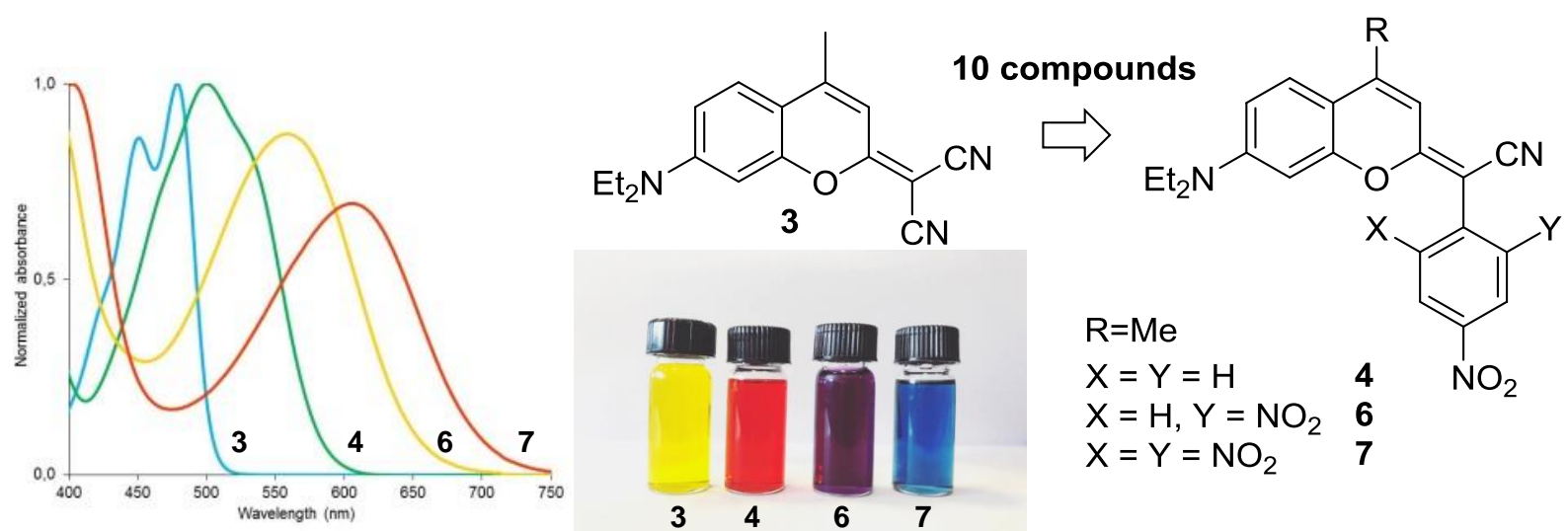


\begin{abstract}
We report the design, synthesis and spectroscopic characterization of a series of pushpull chromophores based on a novel coumarin scaffold in which the carbonyl of the lactone function of the original coumarin dyes has been replaced by the cyano(4nitrophenyl)methylene moiety. The skeleton of the compounds was synthesized by condensation of a thiocoumarin precursor with the corresponding arylacetonitrile derivatives, and their photophysical properties were fine-tuned through the incorporation of electron-withdrawing groups (EWG) like nitro and cyano at the phenyl ring, leading to absorption in the green to red region. Although fluorescence emission was weakened or even cancelled upon introduction of two or three strong EWGs, it is noticeable the emission of the mononitro-containing coumarin derivatives in the red region upon excitation with green light, as well as their significant large Stokes' shifts. The new coumarin derivatives can be useful as photocleavable protecting groups, as demonstrated through the synthesis and characterization of a series of coumarin-based photocages of benzoic acid. Preliminary photolysis studies with green light have demonstrated that the structure of the coumarin chromophore influences on the rate of the uncaging process, opening the way to exploiting these new coumarin scaffolds as caging groups removable with visible light.
\end{abstract}




\section{INTRODUCTION}

The use of photocleavable protecting groups (PPGs or caging groups) has received wide attention in recent years to regulate the activity of biologically relevant molecules, ${ }^{1}$ including drugs based on small compounds ${ }^{2}$ and larger biomolecules (peptides and proteins and oligonucleotides). ${ }^{3}$ The reason relies on the possibility of controlling the release of active species from the corresponding non-biologically active precursors (caged compounds) by using light as an external trigger. Besides offering high spatiotemporal precision, light does not contaminate the living system and its wavelength and intensity can be precisely regulated to make it fully compatible with living systems. ${ }^{4}$ PPGs have also demonstrated great potential in many other fields, including organic synthesis, materials science, industry and agriculture. ${ }^{1 \mathrm{~b}}$

Taking into account the potential of caged compounds as therapeutic agents and as optical tools to study and control complex chemical and biological processes, the selection of the appropriate PPG is of great importance. An ideal caging group must fulfill several requirements including synthetic feasibility and stability under physiological conditions, together with a compatibility with a variety of leaving groups. In addition, it should have a large molar extinction coefficient to allow an efficient uncaging and should not generate toxic by-products. The majority of photoremovable protecting groups reported to date require UV irradiation for photoactivation, which should be avoided given its known phototoxicity ${ }^{5}$ and capacity to interact with endogenous biomolecules. ${ }^{6}$ Moreover, the low capacity of penetration of UV light (even in the UVA range) into deep tissues compromise further therapeutic applications. ${ }^{7}$ In recent years, some promising achievements with PPGs removable upon one-photon excitation in the 400-500 $\mathrm{nm}$ range have been described. ${ }^{\text {bc }}$ However, further work is necessary for the development of new long-wavelength absorbing caging groups removable with one-photon red light $(>600 \mathrm{~nm})$. This non-damaging radiation offers higher efficiencies than alternatives based on two-photon processes and ensures deeper penetration in mammalian tissues due to reduced absorbance. In addition, the availability of red-light absorbing photocages would eventually facilitate the design of complex wavelength-selective uncaging systems that could sequentially remove two or more PPGs from a single compound by using different wavelengths of light. ${ }^{\text {1c }}$ 
With this idea in mind, we decided to choose the $N, N$-diethylamino(coumarin 4yl)methyl moiety as a starting point since the diethylamino electron-donating group (EDG) at position 7 causes larger red shifts in the absorption spectrum than other EDG substituents such as alkoxy. ${ }^{8}$ Moreover, polar groups such as carboxylates could be eventually appended to the aniline moiety to increase, if necessary, the aqueous solubility of the caged compound without significantly compromise the spectral properties of the chromophore. ${ }^{9}$ Recent studies have also demonstrated that modification of $N, N$-dialkyamino substituents at the coumarin's 7-position can be used to improve the photophysical properties of fluorescent dyes such as brightness, photostability and quantum yield. ${ }^{10}$ This coumarinylmethyl platform is easy to synthesize and amenable to structural modifications allowing the attachment of the molecule to be caged through a variety of bonds, including esters, amides, carbamates or carbonates. ${ }^{1 \mathrm{bc}}$ In recent years, thionation of the carbonyl group of the lactone has been used to shift the absorption maximum, which allowed to trigger uncaging with blue-light in different systems, as reported by Jullien, ${ }^{8,11}$ and Costa ${ }^{12}$ groups. Interestingly, the incorporation of two cyano groups at position 2 led to dicyanomethylenecoumarinylmethyl derivatives with maximum absorption around 500 $\mathrm{nm}$ in the 7-diethylamino series. ${ }^{8,13}$ This modification has also been incorporated in coumarin-caged cyclic morpholino oligonucleotides by Deiters, Chen and collaborators for sequential gene silencing, ${ }^{14}$ as well as by us in a caged cyclic RGD peptide for applications in photocontrolled targeted therapies. ${ }^{3 \mathrm{f}}$

Based on these precedents, in this work we have focused on the design and synthesis of new coumarin-based chromophores and explored their applications as visible lightremovable PPGs. As shown in Scheme 1, we reasoned that replacement of one cyano group in the dicyanomethylenecoumarin by a phenyl ring containing electronwithdrawing groups (EWG) at ortho and para positions would increase the push-pull character of the chromophore; ${ }^{15}$ this would result in a large bathochromic shift in the absorption compared with previously reported coumarin derivatives, a typical characteristic of the intramolecular charge-transfer effect. In the first section of this report we describe the design, synthesis and spectroscopic characterization of a small library of model coumarinylmethyl derivatives that explore the effect of EWGs on the photophysical properties of the new chromophores (Scheme 1). In the second section, the best candidates have been functionalized at position 4 of the coumarin moiety 
through an ester bond and their suitability as photocages of carboxylic acids has been explored, using benzoic acid as a model. The photophysical and photochemical properties of two caged model compounds, particularly their photoactivation upon onephoton excitation with green light have also been investigated.

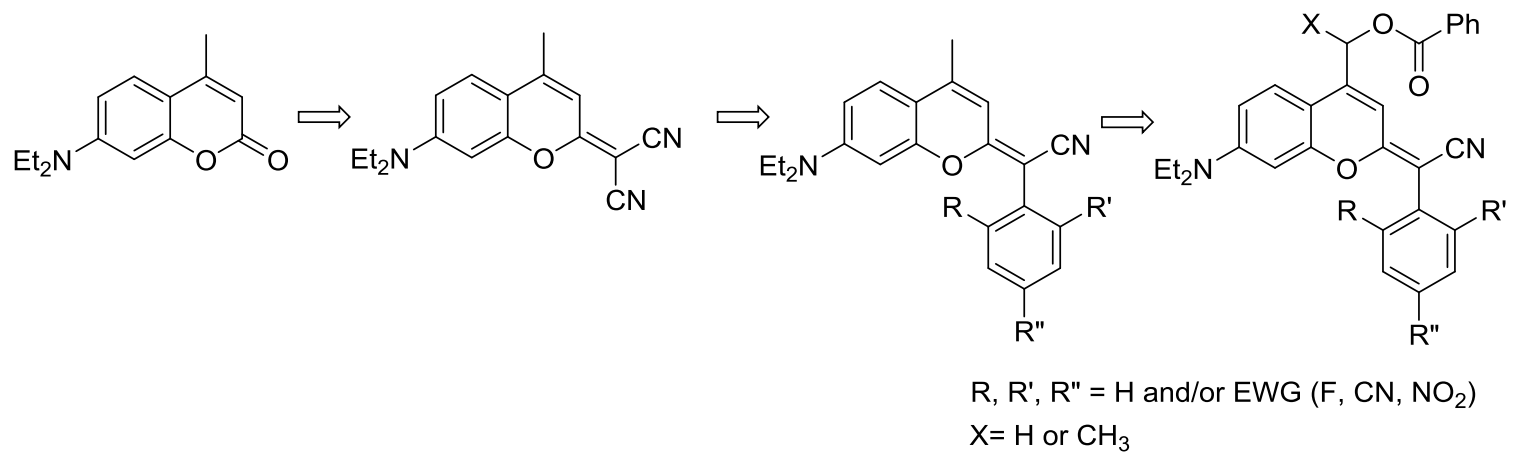

Scheme 1. Design of new coumarin-based chromophores and caging groups by replacement of a cyano group in dicyanocoumarin by a phenyl ring containing EWG at ortho and para positions.

\section{RESULTS AND DISCUSSION}

\section{Design and synthesis of new coumarin-based chromophores with red-shifted}

\section{absorption}

As shown in Scheme 2, we have synthesized a small library of 2-(cyano(4nitrophenyl)methylene coumarin derivatives (4-9) in which one cyano group of the parent dicyanocoumarin (3) has been replaced by a 4-nitrophenyl substituent containing one or two substituents (e.g. cyano, nitro or fluoro) at the ortho positions of the aromatic ring. Since at this stage we wanted to assess the influence of that substitution on the absorption and emission properties of new chromophores, we kept the methyl group at position 4 unaltered. First, 7-(N,N-diethylamino)-4-methyl-2-thiocoumarin (2) was synthesized in $92 \%$ yield by reaction of $\mathbf{1}$ with Lawesson's reagent ${ }^{16}$ in toluene at reflux overnight. Condensation of such thionated coumarin with malononitrile in the presence of triethylamine and silver nitrate ${ }^{3 \mathrm{f}}$ afforded the parent dicyanomethylenecoumarin 3 in $86 \%$ yield after column chromatography.

Next, the reaction of thiocoumarin $\mathbf{2}$ with the commercially available 4nitrophenylacetonitrile (10) led to the desired coumarin derivative 4 (Scheme 2). No reaction occurred with phenylacetonitrile, whose acidity is much lower than that of $\mathbf{1 0}$ $\left(\mathrm{p} K_{\mathrm{a}}=12.3\right)^{17}$ or malononitrile $\left(\mathrm{p} K_{\mathrm{a}}=11.1\right)^{18}$. Taking into account these results and the spectroscopic properties of 4 (see below), we selected the 4-nitrophenyl moiety for 
exploring the incorporation of different substituents at the ortho positions of the aromatic ring $\left(\mathrm{CN}, \mathrm{F}\right.$ and $\left.\mathrm{NO}_{2}\right)$ with the aim of tuning the photophysical properties of the coumarin chromophore. All the required arylacetonitrile compounds (11-15) were synthesized, except 2-(2,4,6-trinitrophenyl)acetonitrile (13), which was commercially available.

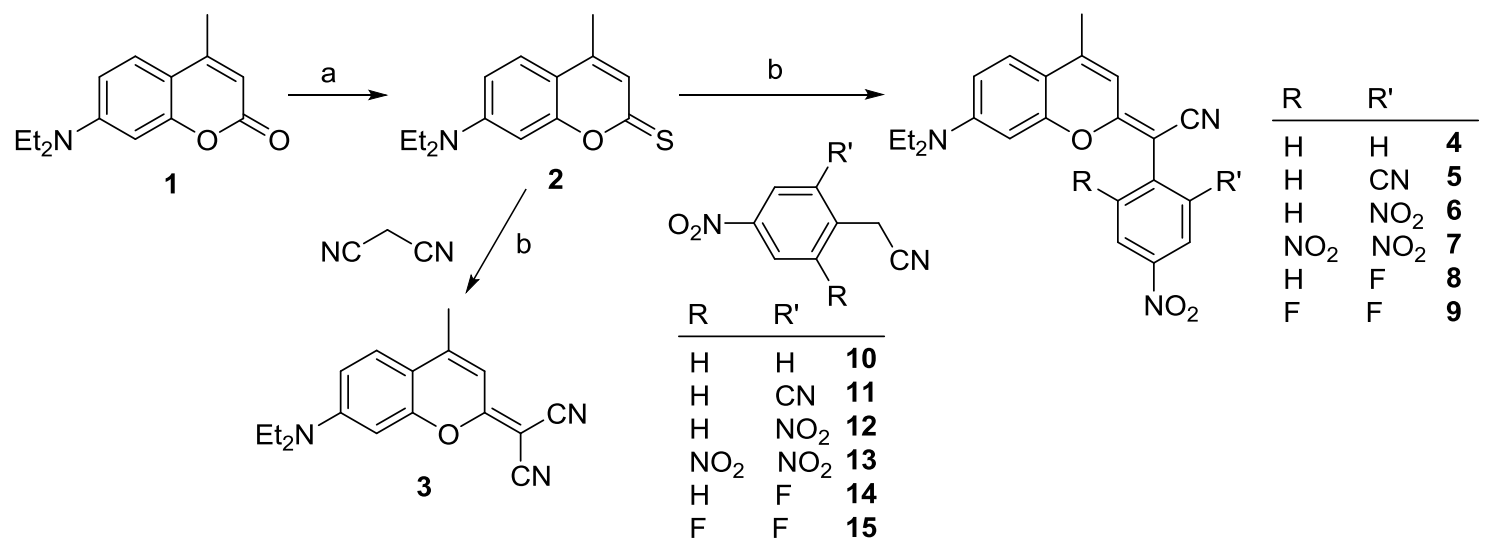

Scheme 2. Synthesis of coumarin-based chromophores 3-9. a) Lawesson's reagent, toluene, $100^{\circ} \mathrm{C}, 12 \mathrm{~h}, 92 \%$; b) Malononitrile or arylacetonitrile derivatives $\mathbf{1 0 - 1 5}$, triethylamine, silver nitrate, anhydrous ACN, rt, 2-4 h, 86\% (3), 40\% (4), 54\% (5), 68\% (6), 27\% (7), 42\% (8), 55\% (9).

As shown in Scheme 3, 2-(2-cyano-4-nitrophenyl)acetonitrile (11) was obtained from 2cyanophenylacetonitrile by nitration with concentrated nitric acid and sulfuric acid at low temperature in $60 \%$ yield. 2-(2,4-dinitrophenyl)acetonitrile (12) was synthesized in two steps from 2,4-dinitrotoluene. First, reaction with $N, N$-dimethylformamide dimethyl acetal provided the corresponding enamine intermediate (16), which was reacted with hydroxylamine hydrochloride and formic acid for $5 \mathrm{~h}$ at $110^{\circ} \mathrm{C}$ to give $\mathbf{1 2}$ (60\% yield) after purification by silica column chromatography. The fluorinated arylacetonitrile derivatives, 2-(2-fluoro-4-nitrophenyl)acetonitrile (14) and 2-(2,6-difluoro-4nitrophenyl)acetonitrile (15) were synthesized in two steps from 1,2-difluoro-4nitrobenzene and 1,2,3-trifluoro-4-nitrobenzene, respectively. Reaction with ethyl cyanoacetate and $\mathrm{K}_{2} \mathrm{CO}_{3}$ in the presence of a catalytic amount of $\mathrm{KI}$ provided the corresponding alkylated intermediates (17 and 18). After hydrolysis of the ester and decarboxylation by reaction with $\mathrm{HCl}$ in a $\mathrm{H}_{2} \mathrm{O} / \mathrm{AcOH}$ mixture, the desired arylacetonitrile derivatives were obtained in moderate yields $\mathbf{1 4}$ (32\%) and $\mathbf{1 5}$ (39\%). 

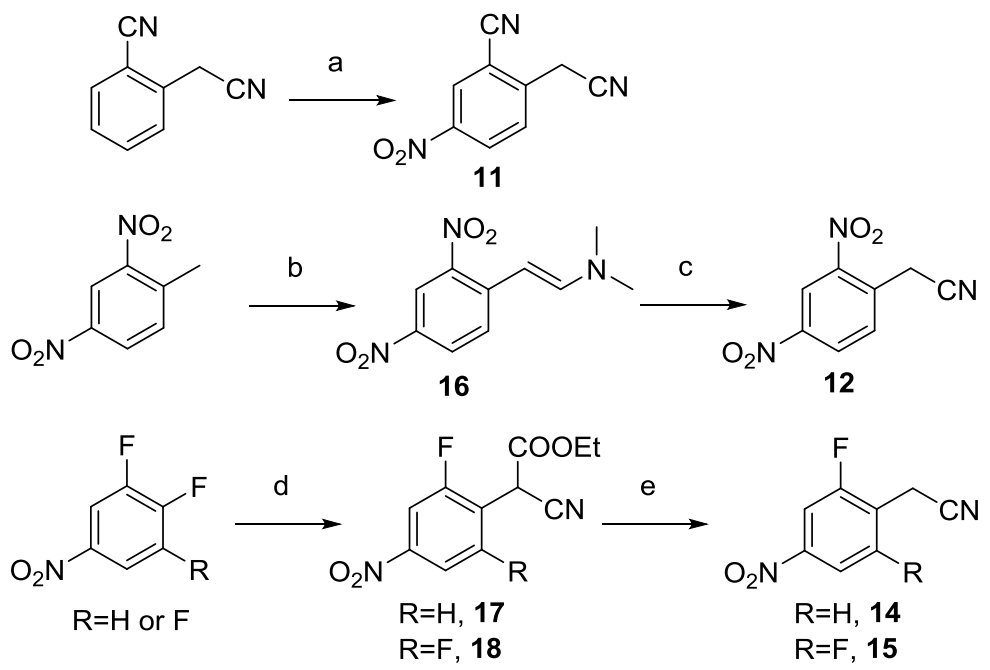

Scheme 3. Synthesis of arylacetonitrile derivatives 11-12 and 14-15. a) $\mathrm{HNO}_{3}, \mathrm{H}_{2} \mathrm{SO}_{4},-5^{\circ} \mathrm{C}, 3$ h, 60\% (11); b) N,N-dimethylformamide dimethylacetal, anhydrous DMF, heat at reflux (16), 15 h, Ar atmosphere, 96\% (16); c) hydroxylamine hydrochloride, formic acid, heat at reflux, $5 \mathrm{~h}$, $60 \%$ (12); d) ethyl cyanoacetate, $\mathrm{K}_{2} \mathrm{CO}_{3}, \mathrm{KI}$, anhydrous DMF, $16 \mathrm{~h}$ at $\mathrm{rt}$ and $2 \mathrm{~h}$ at $100^{\circ} \mathrm{C}, 98 \%$ (17), $72 \%$ (18); e) $\mathrm{HCl}, \mathrm{AcOH}, 12 \mathrm{~h}, 100^{\circ} \mathrm{C}, 32 \%$ (14), 39\% (15).

Coumarins 5-9 (Scheme 2) were synthesized in a similar way that compound 4 by reacting 2 with the corresponding arylacetonitrile derivatives (11-15). All the compounds were isolated by silica column chromatography with moderate to good yields and their purity was assessed by reversed-phase HPLC analysis, revealing a single peak in all cases (Figure S4). Characterization was carried out by usual spectroscopic techniques such as high resolution ESI mass spectrometry and ${ }^{1} \mathrm{H},{ }^{13} \mathrm{C}$ and ${ }^{19} \mathrm{~F}$ NMR. It is worth noting that the ${ }^{1} \mathrm{H}$ NMR spectra of most of the compounds (except for 6 and 7) showed the presence of two sets of proton signals in $\mathrm{CDCl}_{3}$ and in DMSO- $d_{6}$ at $25^{\circ} \mathrm{C}$ in an $\sim$ 95:5 (4; see Figure 1), 90:10 (5) or 80:20 ratio (8 and 9). The same duplicity was found in the ${ }^{13} \mathrm{C}$ NMR spectra as well as in the ${ }^{19} \mathrm{~F}$ NMR spectra of the fluorinated compounds. Taking into account the strong push-pull character of the coumarin derivatives, the exocyclic $\mathrm{C}=\mathrm{C}$ bond connecting the $\mathrm{C}-2$ of the coumarin moiety and the $\mathrm{C}-4$ of the $p$-nitrophenyl cannot be considered a pure double bond but a double bond with partial single bond character due to $\pi$-delocalization. Hence, we hypothesized that rotation around this bond could afford a mixture of two rotamers slowly interconverting in solution rather than two isolated diastereomers. The presence of chemical exchange cross-peaks between the resonances of the two species in the 2D NOESY spectra of compound 4 (Figure 1) as well as in 2D EXSY experiment 
confirmed the presence of rotamers around the exocyclic $\mathrm{C}=\mathrm{C}$ bond. The exchange rate for the rotameric equilibrium $\left(k_{e x}=0.13 \mathrm{~s}^{-1}\right)$ was estimated from the intensities of the exchange cross-peaks and is in agreement with a slow equilibrium on the chemical shift time scale. Full assignment of the ${ }^{1} \mathrm{H}$ NMR spectra of $\mathbf{4}$ with COSY and NOESY experiments (Figures 1, S1-S3) allowed to conclude that the $E$-rotamer was the one preferred in all cases (as drawn in Schemes 1 and 2). The fact that the chemical shift of the proton at position 3 of the coumarin moiety appears at slightly higher $\delta$ in the major isomer (e.g. $6.71 \mathrm{ppm}$ in 4) compared with the minor isomer (e.g. $6.64 \mathrm{ppm}$ in 4) can be attributed to the shielding effect of the phenyl ring over proton $\mathrm{H} 3$ in the $Z$ configuration. A similar trend was found for the chemical shift of the methyl group at position 4 in both isomers (e.g. $2.40 \mathrm{ppm}$ in the $E$-rotamer $v s 2.28 \mathrm{ppm}$ in the Z-rotamer of 4). As shown in Figure 1 and Figures S1, diagnostic NOE cross-peaks such as the one between $\mathrm{H} 3$ proton of the coumarin in the $Z$ isomer and $\mathrm{H}_{\mathrm{m}}$ protons of the $p$ nitrophenyl ring provided further evidence of the structure of the two interconverting rotamers.

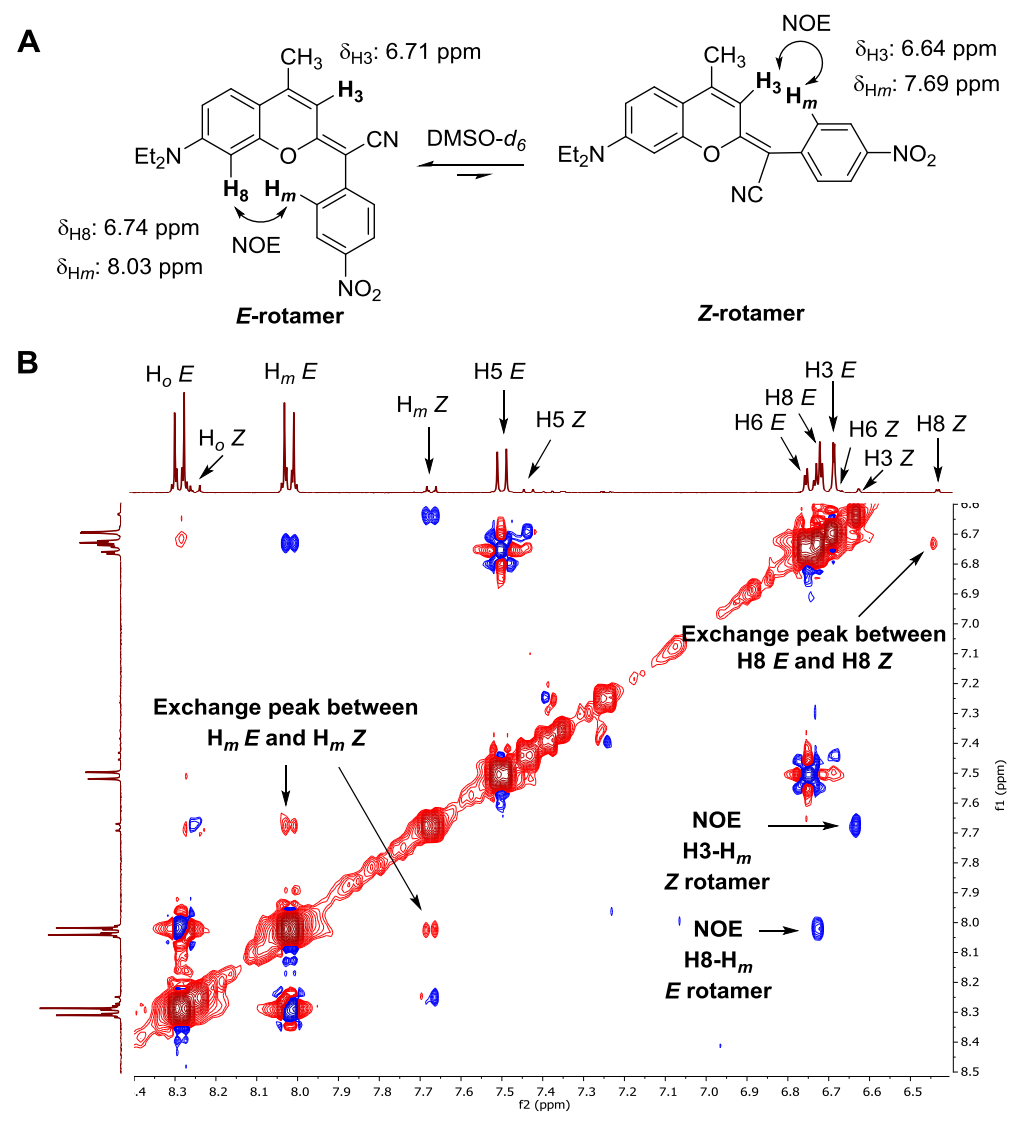

Figure 1. A) Structure of $E$ and $Z$ rotamers of compound 4 with some diagnostic NOE crosspeaks indicated. B) Expansion of the 2D NOESY spectrum $\left(t_{m}=500 \mathrm{~ms}, 25^{\circ} \mathrm{C}\right)$ of compound 4 
in DMSO- $d_{6}$ showing exchange cross-peaks between rotamer resonances of the same sign as the diagonal.

\section{Optical and photophysical properties of coumarin-based chromophores}

The optical and photophysical properties (absorption and emission spectra, molar absorption coefficients and fluorescence quantum yields) of the new coumarin chromophores (4-9) were investigated in two solvents of different polarity (DCM and $\mathrm{MeOH})$. The UV-vis absorption spectra of the compounds are shown in Figures 2 and Figures S6-S7 of the Supporting Information, and their optical and photophysical properties are summarized in Table 1 and Table S1 together with those of the parent dicyanocoumarin (3) which was included for comparison purposes. First, it is worth noting that replacement of one cyano group in $\mathbf{3}$ by $p$-nitrophenyl ring (compound $\mathbf{4}$ ) was positive since it caused a 22-nm bathochromic shift in DCM, thus indicating that this modification increases the push-pull character from the electron-donating group $\left(\mathrm{NEt}_{2}\right)$ to the electron-withdrawing group $\left(\mathrm{NO}_{2}\right)$. As expected, this shift to longer wavelengths was further increased when a second electron-withdrawing substituent like cyano (5) or nitro (6) where introduced in one of the two ortho positions, leading to absorption maxima of $519 \mathrm{~nm}$ (Table S1) and $558 \mathrm{~nm}$, respectively. However, the introduction of one (8) or two (9) fluoro substituents was not beneficial since the absorption maximum shifted slightly to shorter wavelengths (to $485 \mathrm{~nm}$ and $476 \mathrm{~nm}$, respectively; Table S1) when compared with $\mathbf{4}$, which can be attributed to the mesomeric electron-donating character of this substituent. The case of the trinitro coumarin derivative (7) is particularly appealing since the absorption maximum was shifted to $607 \mathrm{~nm}$, being the absorbance still quite significant in the far-red region.
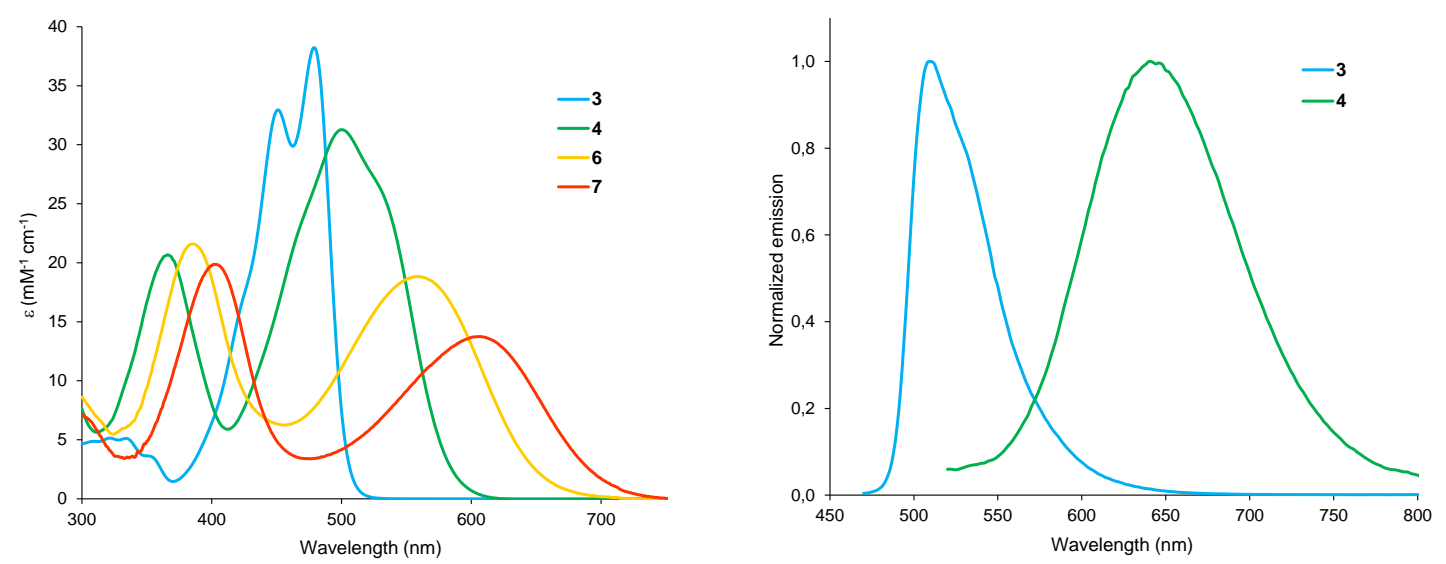

Figure 2. Comparison of the UV-vis spectra of selected coumarin derivatives $\mathbf{3}, \mathbf{4}, \mathbf{6}$ and $\mathbf{7}$ (left) and of fluorescence emission spectra of $\mathbf{3}$ and $\mathbf{4}$ (right) in DCM at RT. 
The molar absorption coefficients were also strongly influenced both by the nature and the number of the EWG at the phenyl ring (e.g. $\varepsilon(4)=31 \mathrm{mM}^{-1} \mathrm{~cm}^{-1} v s \varepsilon(7)=14 \mathrm{mM}^{-1}$ $\mathrm{cm}^{-1}$ ). As shown in Figure 3, all the new coumarin derivatives led to red to blue coloured solutions to the naked eye. It is also worth noting that all the coumarin derivatives (4-9) showed an additional absorption band in the range 365-400 nm, whose maximum absorption was also dependent on the nature and number of EWGs (Table S1). As shown in Table 1, the maximum absorption of $\mathbf{4}$ was slightly blue-shifted in $\mathrm{MeOH}(6 \mathrm{~nm})$ with respect DCM, which is the same behaviour than of the parent coumarin 3 (blue-shifted by $2 \mathrm{~nm}$ ). The dependence of the absorption and emission characteristics of 7-dialkylaminocoumarins with solvent polarity is usually attributed to the strong intramolecular charge transfer character (ICT) of their excited states. ${ }^{19}$ Such negative solvatochromism was particularly dramatic in the case of the dinitro and trinitro-containing compounds (Table 1). For example, the maximum absorption of 7 was shifted from $607 \mathrm{~nm}(\mathrm{DCM})$ to $567 \mathrm{~nm}(\mathrm{MeOH})$ with increasing solvent polarity.

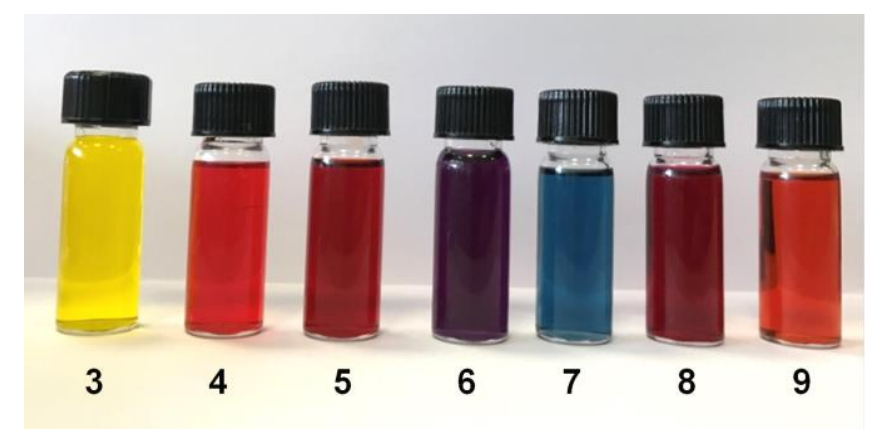

Figure 3. Photographic images of coumarin derivatives 3-9 in DCM under day light.

Table 1. Photophysical properties of coumarin derivatives $3,4,6$ and 7 .

\begin{tabular}{|c|c|c|c|c|c|c|c|c|c|c|}
\hline & \multicolumn{2}{|c|}{$\begin{array}{c}\text { Absorption } \\
\lambda_{\max }[\mathrm{nm}]^{a}\end{array}$} & \multicolumn{2}{c|}{$\begin{array}{c}\varepsilon\left(\lambda_{\max }\right) \\
\left(\mathrm{mM}^{-1} \mathrm{~cm}^{-1}\right)^{b}\end{array}$} & \multicolumn{2}{c|}{$\begin{array}{c}\text { Emission } \\
\lambda_{\max }[\mathrm{nm}]^{c}\end{array}$} & \multicolumn{2}{c|}{$\begin{array}{c}\text { Stokes'shift } \\
(\mathrm{nm})^{d}\end{array}$} & \multicolumn{2}{c|}{$\phi_{\mathrm{F}}{ }^{e}$} \\
\hline Comp. & $\mathrm{MeOH}$ & $\mathrm{DCM}$ & $\mathrm{MeOH}$ & $\mathrm{DCM}$ & $\mathrm{MeOH}$ & $\mathrm{DCM}$ & $\mathrm{MeOH}$ & $\mathrm{DCM}$ & $\mathrm{MeOH}$ & $\mathrm{DCM}$ \\
\hline $\mathbf{3}$ & 477 & 479 & 38 & 38 & 519 & 510 & 42 & 31 & 0.05 & 0.02 \\
\hline $\mathbf{4}$ & $360 / 493$ & $366 / 499$ & $19 / 30$ & $20 / 31$ & $408 / 598$ & $414 / 640$ & 105 & 141 & $<0.001$ & $<0.001$ \\
\hline $\mathbf{6}^{f}$ & $379 / 539$ & $385 / 558$ & $19 / 18$ & $22 / 19$ & $436 /-$ & $415 /-$ & - & - & - & - \\
\hline $7^{f}$ & $396 / 567$ & $402 / 607$ & $15 / 10$ & $20 / 14$ & $449 /-$ & $418 /-$ & - & - & - & - \\
\hline
\end{tabular}

${ }^{a}$ Wavelength of the absorption maximum. ${ }^{b}$ Molar absorption coefficients at both $\lambda_{\max }$ indicated. ${ }^{c}$ Wavelength of the emission maximum upon excitation at a $\lambda_{\text {Ex }}$ positioned within each absorption band. ${ }^{d}$ Stokes' shift for the bands located in the visible region. ${ }^{e}$ Fluorescence quantum yield determined at $25^{\circ} \mathrm{C}$ using either 7-diethylamino-4-methyl-coumarin (coumarin-1, $\lambda_{\mathrm{Ex}}=360 \mathrm{~nm}, \phi_{\mathrm{F}}=0.73$ in ethanol) or 
fluorescein $\left(\lambda_{\mathrm{Ex}}=460 \mathrm{~nm}, \phi_{\mathrm{F}}=0.92\right.$ in aqueous $\left.0.1 \mathrm{M} \mathrm{NaOH}\right)$ as a standard. ${ }^{f}$ No fluorescence detected upon excitation at a $\lambda_{\mathrm{Ex}}$ within the band located in the visible region.

Interestingly, coumarin 4 exhibited very weak dual luminescence in DCM with two maximum emission bands centered in the blue $(414 \mathrm{~nm})$ and far red $(640 \mathrm{~nm})$ regions. However, the overlapping of the emission bands prevented an accurate determination of the fluorescence quantum yield. Nevertheless, it is worth noting the large Stokes'shift of this compound compared with the parent dicyanocoumarin (141 nm for 4 vs $31 \mathrm{~nm}$ for 3, Table 1). Although the emission maximum was also blue-shifted when solvent polarity was increased (from $640 \mathrm{~nm}$ in DCM to $598 \mathrm{~nm}$ in $\mathrm{MeOH}$ ), the Stokes' shift was still considerably high for a 7-dialkylaminocoumarin derivative in a polar solvent $(104 \mathrm{~nm})$. Fluorophores exhibiting large Stokes' shifts are particularly interesting for Förster-type resonance energy transfer (FRET) applications since excitation and emission bands are completely separated. The loss of fluorescence emission in coumarin $\mathbf{4}$ compared to $\mathbf{3}$ is most likely the result of enhanced intramolecular electrontransfer quenching by the nitrophenyl moiety, leading to the formation of a weakly emitting twisted ICT (TICT) excited state (typically non-emissive in 7dialkylaminocoumarins and related amino-containing dyes). ${ }^{10}$ Indeed, examples of the quenching of the native fluorescence of organic dyes through incorporation of nitro substituents are found in the literature. ${ }^{20}$ As expected, dinitro and trinitro-containing coumarins (6 and 7) only showed an extremely weak fluorescence upon excitation at the maximum absorption of the band located in the violet-blue region (Table S1) but no emission was detected upon excitation with visible light.

\section{Photocaging of benzoic acid with nitro-containing coumarin-based derivatives: synthesis and photochemical properties}

The overall results indicate that replacement of one cyano group in coumarin $\mathbf{3}$ by a phenyl ring containing strong EWGs (e.g. $\mathrm{NO}_{2}$ and $\mathrm{CN}$ ) led to coumarin-based chromophores with attractive absorptivity in the biologically benign wavelength range (500-600 nm). Unfortunately, the weak fluorescence of the new coumarin derivatives upon excitation in the visible region rules out their use as fluorophores, particularly the di- and trinitro-containing molecules. For this reason, we decided to explore alternative application such as their use as caging groups removable with visible light by functionalizing the methyl group at position 4 of the coumarin skeleton with an alcohol. 
This approach has been widely exploited to cage several functionalities such as carboxylic acids, amines, thiols or alcohols by using the appropriate chemical bond. ${ }^{1 \mathrm{bc}}$ As shown in Scheme 4, we selected benzoic acid as a model compound to be caged with nitro, dinitro and trinitro-containing coumarinylmethyl derivatives through the formation of an ester bond (25, 26 and 27, respectively). The synthesis of the caged model compounds was planned from 4-(acetoxymethyl)-7-( $N, N$-diethylamino)-2thiocoumarin (22), a key intermediate described by Jullien and collaborators ${ }^{8}$ that can be easily prepared from the commercially available $\mathbf{1}$ in four steps. Hydrolysis of the acetate with $\mathrm{HCl}$ followed by esterification with benzoic acid afforded thiocoumarin $\mathbf{2 4}$, which was reacted with the corresponding arylacetonitrile derivatives $(\mathbf{1 0}, 12$ and 13) to afford the expected caged model compounds (25-27) as single spots on TLC after silica column chromatography. The three compounds were fully characterized by HR ESI-MS and ${ }^{1} \mathrm{H}$ and ${ }^{13} \mathrm{C}$ NMR. As previously found with compound 4 , two sets of proton signals in an $\sim 90: 10$ ratio were identified in the NMR spectra of $\mathbf{2 5}$, whereas a single set of signals was observed for dinitro and trinitro coumarin derivatives. Interestingly, in this case reversed-phase HPLC analysis of 25 showed two peaks $\left(\mathrm{R}_{\mathrm{t}}=26.1\right.$ and $27.9 \mathrm{~min}$, see Figure S5) in an 90:10 ratio. After isolation of the peaks, HPLC re-analysis led to the same initial mixture in both cases, which confirmed the presence of two rotamers under equilibrium and reproduced the behaviour of the model coumarin 4.

Recently, we have demonstrated that both the structure of the coumarin chromophore and the nature of the leaving group have a strong influence on the rate and efficiency of the uncaging process. ${ }^{21}$ Indeed, the incorporation of a methyl group at the 4-position of dicyanocoumarinylmethyl (DEAdcCM) derivatives led to new dicyanocoumarinylethyl (DEAdcCE)-photocleavable protecting groups that can be removed upon green light irradiation more efficiently from the corresponding caged carboxylic acids and amines. $^{21}$ This result can be attributed to the higher stability of the secondary carbocation intermediate generated upon photoheterolysis of the $\mathrm{C}-\mathrm{O}$ bond in the corresponding caged compounds. Taking into account these precedents, we decided to synthesize the caged model compound 28 (Scheme 4) with the aim of comparing its photolysis with that of the non-methylated analogue (25). Compound 28 was efficiently synthesized by reaction of the thiocoumarin precursor $\mathbf{3 2}^{21}$ (Scheme 4) with arylacetonitrile 10. According to HPLC and NMR analysis, two rotamers in an $\sim 85: 15$ ratio were also identified for compound 32, which parallels the behavior of $\mathbf{4}$ and $\mathbf{2 5}$. 


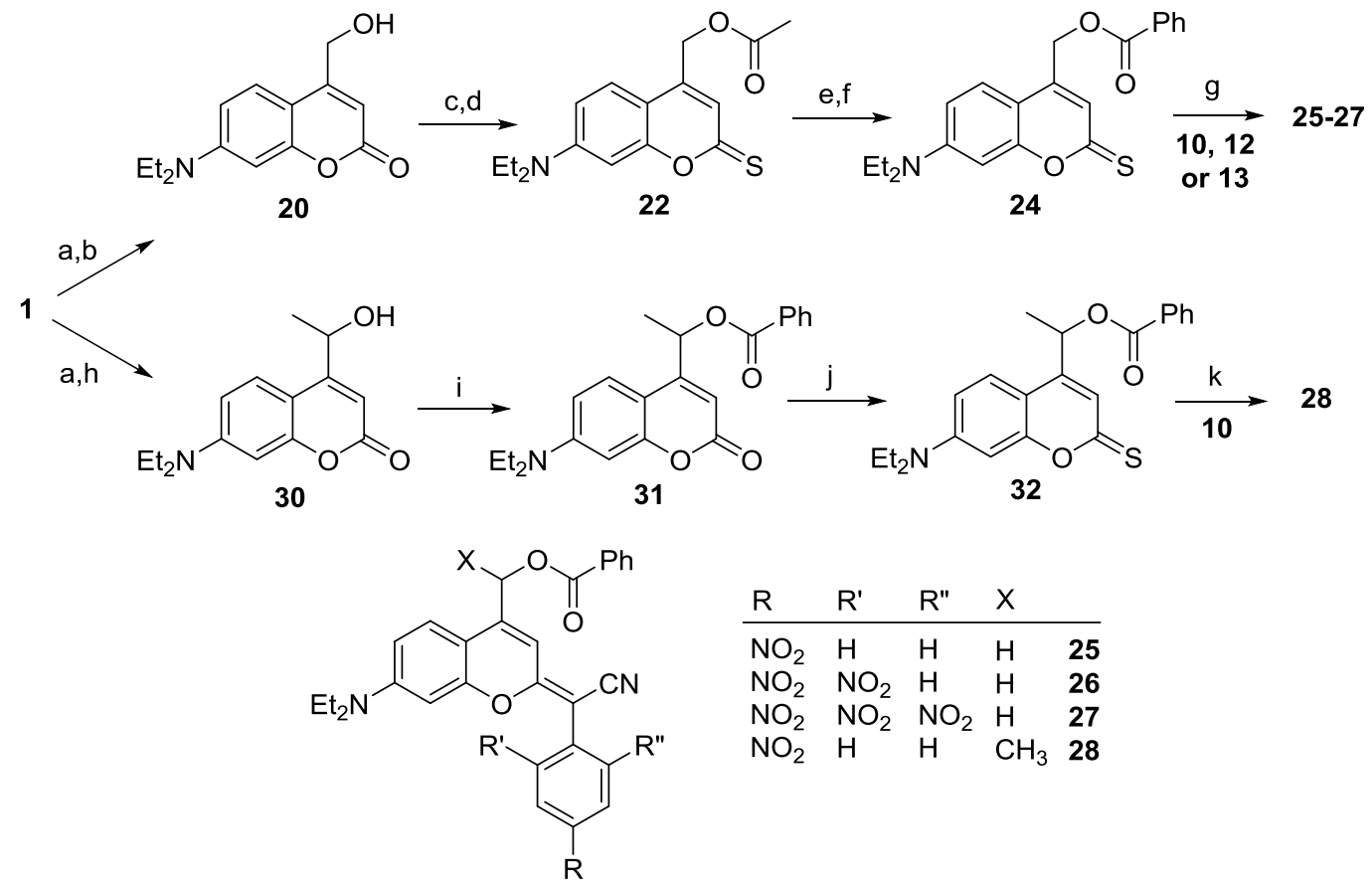

Scheme 4. Synthesis of caged model compounds 25-28. a) $\mathrm{SeO}_{2}$, dioxane/ $\mathrm{H}_{2} \mathrm{O}$ 1:0.03 (v/v), heat at reflux, 15 days, 40\%; b) $\mathrm{NaBH}_{4}$, EtOH, 4 h, RT, 90\%; c) AcOH, EDC.HCl, DMAP, DCM, 12 h, RT, Ar, 73\%; d) Lawesson's reagent, toluene, 15 h, heat at reflux, 76\%; e) $\mathrm{HCl}, \mathrm{EtOH}, 20$ h, $90^{\circ} \mathrm{C}$; f) Benzoic acid, EDC.HCl, DMAP, DCM, 18 h, RT, Ar, 72\% (2 steps e + f); g) first, arylacetonitrile derivatives 10, 12 or $\mathbf{1 3}+\mathrm{NEt}_{3}$ in anhydrous ACN or ACN/DCM 1:12 h RT, then $\mathrm{AgNO}_{3} 2$ h RT, 70\% (25), $41 \%$ (26), 8\% (27); h) $\mathrm{CH}_{3} \mathrm{MgCl}$, anh. THF, 4 h, $-78^{\circ} \mathrm{C}, 71 \%$; i) Benzoic acid, EDC·HCl, DMAP, DCM, 18 h, RT, Ar; j) Lawesson's reagent, toluene, 15 h, heat at reflux, 69\% (2 steps $\mathrm{i}+\mathrm{j}$ ); k) first, $10+\mathrm{NEt}_{3}$ in anhydrous ACN/DCM 1:1 $2 \mathrm{~h} \mathrm{RT}$, then $\mathrm{AgNO}_{3} 2$ h RT, 69\% (28).

By comparison of the photophysical data (Figure 4 and Table 2) of the three caged derivatives (25-27) with those of the corresponding model compounds $(\mathbf{4}, \mathbf{6}$ and $\mathbf{7}$, respectively; see Figure 2 and Table 1), the same tendency was found: the absorption maxima shifted to increasingly longer wavelengths upon incorporation of one, two or three nitro substituents at the ortho and para positions of the phenyl ring conjugated at the 2-position of the coumarin moiety. However, replacement of the methyl group at position 4 by benzoyloxymethyl caused a slight blue-shift in the absorption maximum of the dinitro- $(558 \mathrm{~nm}$ in 6 vs $551 \mathrm{~nm}$ in 26) and the trinitro- $(607 \mathrm{~nm}$ in 7 vs $596 \mathrm{~nm}$ in 27) coumarin derivatives. Similarly, the molar absorption coefficients were strongly influenced by the nature and the number of the EWG at the phenyl ring, and only the mononitro-containing compound showed weak fluorescence upon excitation in the visible region (Table 2). In agreement with our previous results with dicyanocoumarin 
derivatives, ${ }^{21}$ the incorporation of the methyl group at the coumarin skeleton caused an additional red-shift when compared with non-methylated analogues (e.g. compare $\mathbf{2 5}$ and $\mathbf{2 8}$ ) as well as a slight increase of the molar absorption coefficient.

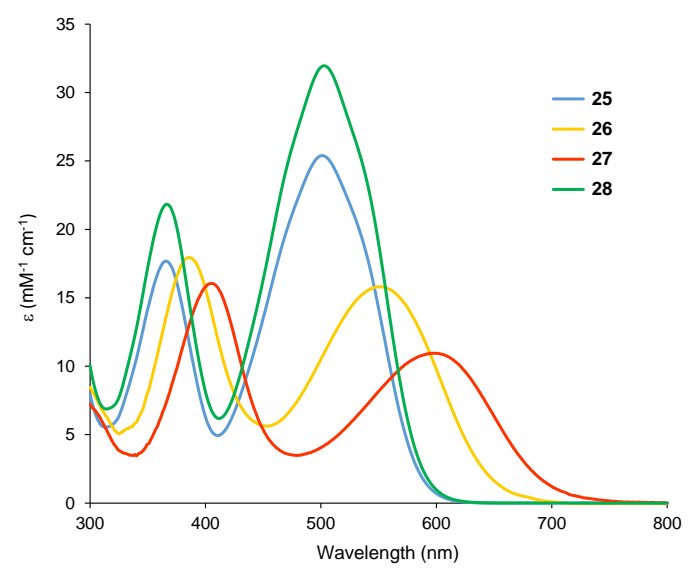

Figure 4. Comparison of the UV-vis spectra of coumarin derivatives 25-28 in DCM at RT.

Table 2. Photophysical properties of coumarin derivatives 25-28 in DCM.

\begin{tabular}{|c|c|c|c|c|}
\hline Comp. & $\begin{array}{c}\text { Absorption } \\
\lambda_{\max }[\mathrm{nm}]^{a}\end{array}$ & $\begin{array}{c}\varepsilon\left(\lambda_{\max }\right) \\
\left(\mathrm{mM}^{-1} \mathrm{~cm}^{-1}\right)^{b}\end{array}$ & $\begin{array}{c}\text { Emission } \\
\lambda_{\max }[\mathrm{nm}]^{c}\end{array}$ & $\begin{array}{c}\text { Stokes'shift } \\
(\mathrm{nm})^{d}\end{array}$ \\
\hline $\mathbf{2 5}$ & $366 / 501$ & $18 / 25$ & $414 / 634$ & 133 \\
\hline $\mathbf{2 6}$ & $386 / 551$ & $18 / 16$ & $441 /-$ & - \\
\hline $\mathbf{2 7}$ & $405 / 596$ & $16 / 11$ & $445 /-$ & - \\
\hline $\mathbf{2 8}$ & $367 / 503$ & $22 / 32$ & $414 / 635$ & 132 \\
\hline
\end{tabular}

${ }^{a}$ Wavelength of the two absorption maximum. ${ }^{b}$ Molar absorption coefficients at both $\lambda_{\max }$ indicated. ${ }^{c}$ Wavelength of the emission maximum upon excitation at a $\lambda_{\text {Ex }}$ positioned within each absorption band. ${ }^{d}$ Stokes' shift for the bands located in the visible region. ${ }^{e}$ No fluorescence detected upon excitation at a $\lambda_{\mathrm{Ex}}$ located within the band in the visible region.

Preliminary photolysis studies were carried out by irradiating a solution of caged model compounds 25 and 28 in $\mathrm{MeOH}$ at $37^{\circ} \mathrm{C}$ with a $505 \mathrm{~nm}$ LED source, ${ }^{3 \mathrm{f}}$ and the course of the uncaging process was monitored by reversed-phase HPLC-ESI MS. As shown in Scheme 5 and Figures S8-S9, photoactivation of $\mathbf{2 5}$ and $\mathbf{2 8}$ yielded the corresponding photolytic by-products $\mathbf{3 3}$ and $\mathbf{3 4}$, respectively, as well as the uncaged benzoic acid. The formation of methoxy-coumarin derivatives supports a solvent-assisted photoheterolytic bond cleavage upon electronic excitation via a cationic intermediate that reacts with methanol. It is worth noting that the photorelease of the caged model compounds was very slow under the conditions employed, particularly in the case of coumarin 25. Indeed, only a $2 \%$ of deprotection was achieved after $5 \mathrm{~h}$ of irradiation, and this 
percentage was only increased to $4 \%$ after 10 h. By contrast, photolysis of coumarin 28 was considerably more efficient $(11 \%$ and $18 \%$ of deprotection after $5 \mathrm{~h}$ and $10 \mathrm{~h}$ of irradiation, respectively), which can be attributed to the different stability of the carbocation intermediates (primary in $\mathbf{2 5}$ and secondary in 28) generated during photoheterolysis of the ester. This is in good agreement with our previous results with dicyanocoumarin-caged model compounds. ${ }^{21}$ Finally, the uncaging quantum yields $\left(\phi_{\text {Phot }}\right)$ of the two caged model compounds were evaluated upon irradiation at $505 \mathrm{~nm}$ (see the Experimental Section for further details) ${ }^{21}$ as $\phi_{\text {Phot }}=5.3 \times 10^{-7}$ for 25 and $\phi_{\text {Phot }}=$ $2.3 \times 10^{-6}$ for $\mathbf{2 8}$, which agrees with the results from the photolysis studies.

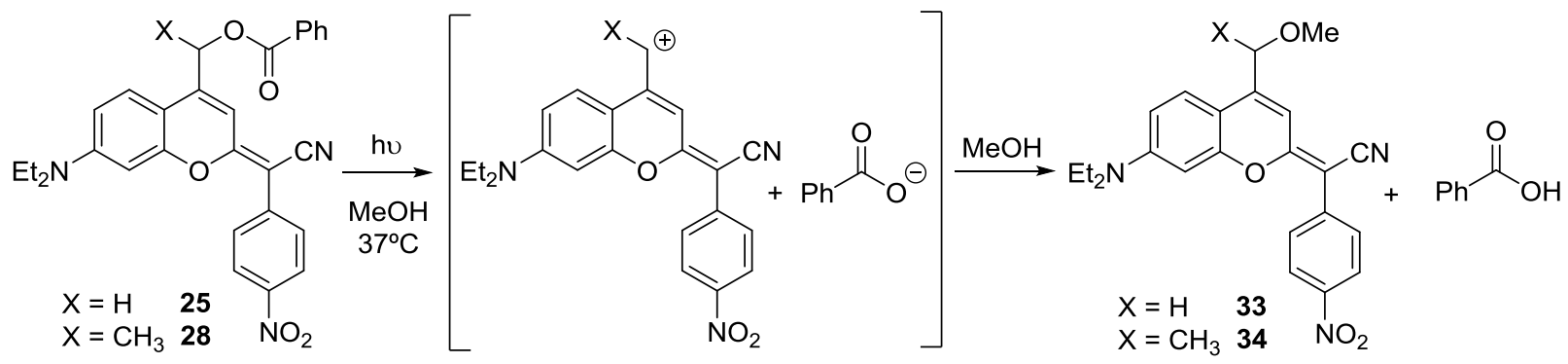

Scheme 5. Photolysis of coumarin derivatives $\mathbf{2 5}$ and $\mathbf{2 8}$ with green light.

\section{CONCLUSIONS}

In summary, we have designed and synthesized a series of push-pull chromophores based on a novel coumarin scaffold containing a cyano(4-nitrophenyl)methylene moiety at position 2. The compounds can be readily prepared through condensation of a thiocoumarin precursor with arylacetonitrile derivatives in the presence of triethylamine and silver nitrate. The optical and photophysical properties of the chromophores can be fine-tuned by incorporating electron-withdrawing groups such as nitro and cyano at the ortho and para positions of the phenyl ring, which shifts the absorption bands to the visible region of the electromagnetic spectrum $(500-650 \mathrm{~nm})$ in a solvent-dependent manner. Notably, green light excitation of the mononitro-containing coumarins led to emission in the red region with significant large Stokes'shifts even in polar solvents, although with very low quantum yields. Unfortunately, the incorporation of two or three strong EWGs weakened or even cancelled the fluorescence emission of the compounds, which agrees with previous findings on other nitro-containing dyes. On the other hand, the compounds were further used to synthesize a series of coumarin-based photocages of benzoic acid to ascertain their use as photocleavable protecting groups removable 
with visible light. Preliminary photolysis studies with green light have demonstrated that the structure of the coumarin chromophore has a strong influence on the rate of the uncaging process. Work is in progress to increase the red-shifted properties of the new coumarin derivatives described in this work to facilitate uncaging in the far-red and near-IR region, ${ }^{24}$ as well as to improve their photophysical properties, especially fluorescence emission.

\section{EXPERIMENTAL SECTION}

\section{Materials and Methods}

Unless otherwise stated, common chemicals and solvents (HPLC grade or reagent grade quality) were purchased from commercial sources and used without further purification. 2-(2,4,6-trinitrophenyl)acetonitrile (13) was purchased from SelectLab Chemicals $\mathrm{GmbH}$. Aluminium plates coated with a $0.2 \mathrm{~mm}$ thick layer of silica gel $60 \mathrm{~F}_{254}$ were used for thin-layer chromatography analyses (TLC), whereas flash column chromatography purification was carried out using silica gel 60 (230-400 mesh). Reversed-phase high-performance liquid chromatography (HPLC) analyses were carried out on a Jupiter Proteo $\mathrm{C}_{18}$ column $(250 \mathrm{x} 4.6 \mathrm{~mm}, 90 \AA 4 \mu \mathrm{m}$, flow rate: 1 $\mathrm{mL} / \mathrm{min}$ ) using linear gradients of $0.045 \%$ TFA or $0.1 \%$ formic acid in $\mathrm{H}_{2} \mathrm{O}$ (A) and $0.036 \%$ TFA or $0.1 \%$ formic acid in ACN (B). NMR spectra were recorded at $25^{\circ} \mathrm{C}$ in a $400 \mathrm{MHz}$ spectrometer using deuterated solvents. Tetramethylsilane (TMS) was used as an internal reference $(0 \mathrm{ppm})$ for ${ }^{1} \mathrm{H}$ spectra recorded in $\mathrm{CDCl}_{3}$ and the residual signal of the solvent (77.16 ppm) for ${ }^{13} \mathrm{C}$ spectra. For NMR spectra recorded in DMSO- $d_{6}$, the residual signal of the solvent was used to reference ${ }^{1} \mathrm{H}$ and ${ }^{13} \mathrm{C}$ chemical shifts. Chemical shifts are reported in part per million (ppm) in the $\delta$ scale, coupling constants in $\mathrm{Hz}$ and multiplicity as follows: s (singlet), d (doublet), t (triplet), q (quadruplet), qt (quintuplet), m (multiplet), dd (doublet of doublets), td (doublet of triplets), ddd (doublet of doublet of doublets), br (broad signal). 2D-NOESY spectra were acquired in DMSO- $d_{6}$ with mixing times of 300 and $500 \mathrm{~ms}$, and 2D-EXSY experiments were carried out with the conventional NOESY pulse sequence using a mixing time of $1 \mathrm{~s}$. The proton signals of the $E$ and $Z$ rotamers were identified by simple inspection of the

${ }^{1} \mathrm{H}$ spectrum and the rotamer ratio was calculated by peak integration. Exchange rate $\left(k_{e x}\right)$ was estimated by plotting the intensity ratio for exchange cross-peaks and the corresponding diagonal peaks in NOESY spectra as a function of the mixing time. ${ }^{25}$ Electrospray ionization mass spectra (ESI-MS) were recorded on an instrument 
equipped with single quadrupole detector coupled to an HPLC, and high-resolution (HR) ESI-MS on a LC/MS-TOF instrument. A TOF analyser was used for mass spectra obtained via electron impact ionization $(\mathrm{EI})$, and values in parentheses indicate relative intensities with regard to the base peak.

\section{Synthesis of arylacetonitrile derivatives (11-15).}

2-(2-Cyano-4-nitrophenyl)acetonitrile (11). A modified method was followed to synthesize compound $11{ }^{26}$-cyanophenylacetonitrile ( $\left.5 \mathrm{~g}, 35.2 \mathrm{mmol}\right)$ was dissolved in concentrated sulfuric acid $(2 \mathrm{~mL})$ cooled at $0^{\circ} \mathrm{C}$. Then, a solution of nitric acid $(1.5 \mathrm{~mL})$ in sulfuric acid $(7.1 \mathrm{~mL})$ was added dropwise within $40 \mathrm{~min}$, so that the temperature of the reaction mixture did not exceed $5^{\circ} \mathrm{C}$. After stirring for $2.5 \mathrm{~h}$ at $-5^{\circ} \mathrm{C}$, the reaction mixture was poured over ice and treated with sodium carbonate until $\mathrm{pH}$ 8-9 was reached. The solid was filtered, washed with water and dried in vacuum. After purification by column chromatography (silica gel, from 50\% hexane in DCM to $100 \%$ DCM, then to $0.1 \%$ of $\mathrm{MeOH}$ in DCM), a yellow solid was obtained (3.96 g, 60\%): $\mathrm{mp}$ 108-110 ${ }^{\circ} \mathrm{C}$; TLC: $R_{f}(\mathrm{DCM})$ 0.34; ${ }^{1} \mathrm{H}$ NMR $\left(400 \mathrm{MHz}, \mathrm{CDCl}_{3}\right) \delta(\mathrm{ppm}): 8.58(1 \mathrm{H}, \mathrm{d}$, $J=2.4 \mathrm{~Hz}), 8.54(1 \mathrm{H}, \mathrm{dd}, J=8.8 \mathrm{~Hz}, J=2.4 \mathrm{~Hz}), 7.95(1 \mathrm{H}, \mathrm{d}, J=8.8 \mathrm{~Hz}), 4.13(2 \mathrm{H}, \mathrm{s})$; ${ }^{13} \mathrm{C}\left\{{ }^{1} \mathrm{H}\right\}$ NMR (101 MHz, $\left.\mathrm{CDCl}_{3}\right) \delta$ (ppm): 147.7, 140.0, 130.4, 128.3, 128.1, 114.6, 114.5, 113.8, 22.9; MS (EI): $m / z 187\left(\mathrm{M}^{+}, 97\right), 141$ (100), 114 (84) (calcd mass for $\mathrm{C}_{9} \mathrm{H}_{5} \mathrm{~N}_{3} \mathrm{O}_{2}[\mathrm{M}]^{+}:$187).

2-(2,4-Dinitrophenyl)acetonitrile (12). The published method with some modifications was followed to synthesize compound $12 .{ }^{27} \mathrm{~N}, \mathrm{~N}$-dimethylformamide dimethyl acetal (71 mL, $530 \mathrm{mmol})$ was added to a solution of 2,4-dinitrotoluene (20 g, $106 \mathrm{mmol})$ in dry DMF (150 mL). The reaction mixture was stirred at $160^{\circ} \mathrm{C}$ under an Ar atmosphere for $15 \mathrm{~h}$. Then, the solvent was removed under vacuum. The crude was dissolved in DCM and precipitated upon addition of cold hexane to give (E)-2-(2,4-dinitrophenyl)$N, N$-dimethyl-1-ethenamine (16) as a red solid (24.3 g, 96\%), which was used without further purification. Characterization for 16: ${ }^{1} \mathrm{H} \mathrm{NMR}\left(400 \mathrm{MHz}, \mathrm{CDCl}_{3},\right) \delta(\mathrm{ppm}): 8.73$ $(1 \mathrm{H}, \mathrm{d}, J=2.4 \mathrm{~Hz}), 8.04(1 \mathrm{H}, \mathrm{dd}, J=9.2 \mathrm{~Hz}, J=2.4 \mathrm{~Hz}), 7.49(1 \mathrm{H}, \mathrm{d}, J=9.2 \mathrm{~Hz}), 7.31(1 \mathrm{H}$, d, $J=13 \mathrm{~Hz}), 6.04(1 \mathrm{H}, \mathrm{d}, J=13 \mathrm{~Hz}), 3.06(6 \mathrm{H}, \mathrm{s})$. Compound 16 (24.2 g, $102 \mathrm{mmol})$ and hydroxylamine hydrochloride $(10.6 \mathrm{~g}, 153 \mathrm{mmol})$ were dissolved in formic acid (150 $\mathrm{mL}$ ) and the reaction mixture was stirred at $110^{\circ} \mathrm{C}$ for $5 \mathrm{~h}$. After removal of the solvent under vacuum, the crude was dissolved in toluene and evaporated again under reduced pressure. The crude was dissolved in DCM $(100 \mathrm{~mL})$ and washed with saturated 
$\mathrm{NaHCO}_{3}(3 \times 50 \mathrm{~mL})$ and brine $(1 \times 50 \mathrm{~mL})$. The combined organic layers were dried over anhydrous $\mathrm{MgSO}_{4}$ and filtered. The solvent was removed under vacuum and the product was purified by column chromatography (silica gel, 50-100\% of DCM in hexane). The appropriate fractions were collected and the solvents were removed under vacuum to give of a brown solid, which was used without further purification (12.6 g, 60\%): $\mathrm{mp}$ 91-92 ${ }^{\circ} \mathrm{C}$; TLC: $R_{f}(\mathrm{DCM}) 0.70 ;{ }^{1} \mathrm{H} \mathrm{NMR}\left(400 \mathrm{MHz}, \mathrm{CDCl}_{3}\right) \delta(\mathrm{ppm}): 9.03(1 \mathrm{H}, \mathrm{d}$, $J=2.4 \mathrm{~Hz}), 8.57(1 \mathrm{H}, \mathrm{dd}, J=8.4 \mathrm{~Hz}, J=2.4 \mathrm{~Hz}), 8.04(1 \mathrm{H}, \mathrm{d}, J=8.4 \mathrm{~Hz}), 4.34(2 \mathrm{H}, \mathrm{s})$; ${ }^{13} \mathrm{C}\left\{{ }^{1} \mathrm{H}\right\} \mathrm{NMR}\left(101 \mathrm{MHz}, \mathrm{CDCl}_{3}\right) \delta(\mathrm{ppm}): 148.2,147.8,132.7,132.2,128.5,121.4$, 115.2, 23.1; MS (EI): m/z $207\left(\mathrm{M}^{+}, 2\right), 180$ (100), 134 (95), 114 (58) (calcd mass for $\mathrm{C}_{8} \mathrm{H}_{5} \mathrm{~N}_{3} \mathrm{O}_{4}[\mathrm{M}]^{+}:$207).

Ethyl 2-cyano-2-(2-fluoro-4-nitrophenyl)acetate (17). The published method with some modifications was followed to synthesize compound $17 .^{28}$ 1,2-difluoro-4-nitrobenzene $(5 \mathrm{~g}, 31.4 \mathrm{mmol})$ was added to a solution of KI (56 mg, $0.33 \mathrm{mmol})$, ethyl cyanoacetate (3.9 g, $34.5 \mathrm{mmol})$ and $\mathrm{K}_{2} \mathrm{CO}_{3}(6.0 \mathrm{~g}, 44.0 \mathrm{mmol})$, finely blended, in anhydrous $\mathrm{DMF}$ $(50 \mathrm{~mL})$. The reaction mixture was stirred first at room temperature for $16 \mathrm{~h}$, and then at $100^{\circ} \mathrm{C}$ for $2 \mathrm{~h}$. After removal of the solvent under vacuum, the crude was partitioned between aqueous citric acid $1 \mathrm{M}(75 \mathrm{~mL})$ and ethyl acetate $(75 \mathrm{~mL})$, and the layers were separated. The aqueous layer was washed with ethyl acetate $(50 \mathrm{~mL})$ two times. Finally, the combined organic layers were washed with brine $(50 \mathrm{~mL})$, dried over anhydrous $\mathrm{MgSO}_{4}$ and filtered. After removal of the solvent, a purple solid were obtained and used without further purification $(7.75 \mathrm{~g}, 98 \%)$; TLC: $R_{f}(\mathrm{DCM}) 0.80 ;{ }^{1} \mathrm{H}$ NMR $(400 \mathrm{MHz}$, $\left.\mathrm{CDCl}_{3}\right) \delta(\mathrm{ppm}): 8.15(1 \mathrm{H}, \mathrm{ddd}, \mathrm{J}=8.8 \mathrm{~Hz}, J=2.4 \mathrm{~Hz}, J=1.2 \mathrm{~Hz}), 8.04(1 \mathrm{H}, \mathrm{dd}, J=9.2$ $\mathrm{Hz}, J=2.4 \mathrm{~Hz}), 7.77(1 \mathrm{H}, \mathrm{dd}, J=8.4 \mathrm{~Hz}, J=7.2 \mathrm{~Hz}), 5.09(1 \mathrm{H}, \mathrm{s}), 4.32$ (2H, qd, $J=7.2$ $\mathrm{Hz}), 1.33(3 \mathrm{H}, \mathrm{t}, J=7.2 \mathrm{~Hz}) ;{ }^{13} \mathrm{C}\left\{{ }^{1} \mathrm{H}\right\} \mathrm{NMR}\left(101 \mathrm{MHz}, \mathrm{CDCl}_{3}\right) \delta(\mathrm{ppm}): 162.7,159.6$ (d, $J=256 \mathrm{~Hz}), 149.5$ (d, J=8.7 Hz), 130.8 (d, J=2.5 Hz), 124.8 (d, J=15 Hz), 120.0 (d, $J=3.8 \mathrm{~Hz}$ ), 113.7, 112.0 (d, $J=26.6 \mathrm{~Hz}), 64.3,37.3$ (d, $J=3.2 \mathrm{~Hz}), 13.9 ;{ }^{19} \mathrm{~F}$ NMR (375 $\left.\mathrm{MHz}, \mathrm{CDCl}_{3}\right) \delta(\mathrm{ppm}):-111.2(1 \mathrm{~F}, \mathrm{~m})$.

2-(2-Fluoro-4-nitrophenyl)acetonitrile (14). The published method with some modifications was followed to synthesize compound $14 .^{28}$ Compound 17 (7.7 g, 30.5 mmol ) was dissolved in a mixture of water/acetic acid $(22.5 \mathrm{~mL} / 7.5 \mathrm{~mL})$ and then $37 \% \mathrm{HCl}(4 \mathrm{~mL})$ was added. The solution was stirred and heated at $100^{\circ} \mathrm{C}$ for $12 \mathrm{~h}$. After quenching with saturated $\mathrm{NaHCO}_{3}(100 \mathrm{~mL})$, the reaction was extracted three times with diethyl ether $(40 \mathrm{~mL})$. The combined organics layers were collected and washed with brine $(50 \mathrm{~mL})$, dried over anhydrous $\mathrm{MgSO}_{4}$ and filtered. Finally, the 
solvent was removed under vacuum. The product was purified by column chromatography (silica gel, DCM). The appropriate fractions were collected and the solvent was removed to give a purple solid $(1.73 \mathrm{~g}, 32 \%)$ : $\mathrm{mp} 79-81{ }^{\circ} \mathrm{C}$; TLC: $R_{f}(\mathrm{DCM})$ 0.45; ${ }^{1} \mathrm{H}$ NMR (400 MHz, $\left.\mathrm{CDCl}_{3}\right) \delta(\mathrm{ppm}): 8.12(1 \mathrm{H}, \mathrm{m}), 8.01(1 \mathrm{H}, \mathrm{dd}, J=9.4 \mathrm{~Hz}, J=2.2$ $\mathrm{Hz}), 7.71(1 \mathrm{H}, \mathrm{m}), 3.89(2 \mathrm{H}, \mathrm{s}) ;{ }^{13} \mathrm{C}\left\{{ }^{1} \mathrm{H}\right\} \mathrm{NMR}\left(101 \mathrm{MHz}, \mathrm{CDCl}_{3}\right) \delta(\mathrm{ppm}): 157.1$ (d, $J=255 \mathrm{~Hz}), 148.9$ (d, J=7.1 Hz), 130.4, 124.8 (d, J=15.7 Hz), 119.9 (d, J=3.8 Hz), 115.3, 111.6 (d, J=26 Hz), 17.9 (d, $J=5 \mathrm{~Hz}) ;{ }^{19} \mathrm{~F}$ NMR $\left(375 \mathrm{MHz}, \mathrm{CDCl}_{3}\right): \delta(\mathrm{ppm})$ : $112.0(1 \mathrm{~F}, \mathrm{~m})$; MS (EI): m/z $180\left(\mathrm{M}^{+}, 100\right), 134$ (66), 107 (84) (calcd mass for $\left.\mathrm{C}_{8} \mathrm{H}_{5} \mathrm{FN}_{2} \mathrm{O}_{2}[\mathrm{M}]^{+}: 180\right)$.

Ethyl-2-cyano-2-(2,6-difluoro-4-nitrophenyl)acetate (18). A modified method was followed to synthesize compound $\mathbf{1 8}^{28}$ 1,2,3-trifluoro-5-nitrobenzene (4.8 g, 27.1 $\mathrm{mmol})$ was added to a solution of $\mathrm{KI}(44.7 \mathrm{mg}, 0.26 \mathrm{mmol})$, ethyl cyanoacetate $(3.4 \mathrm{~g}$, $52.2 \mathrm{mmol}$ ), and $\mathrm{K}_{2} \mathrm{CO}_{3}(5.28 \mathrm{~g}, 38.2 \mathrm{mmol})$, finely blended, in anhydrous DMF (90 $\mathrm{mL}$ ). The reaction mixture was stirred first at room temperature for $20 \mathrm{~h}$, and then at $100^{\circ} \mathrm{C}$ for $2 \mathrm{~h}$. After removal of the solvent under vacuum, the crude was partitioned between citric acid $1 \mathrm{M}(75 \mathrm{~mL})$ and ethyl acetate $(75 \mathrm{~mL})$. The aqueous layer was washed with ethyl acetate $(2 \times 50 \mathrm{~mL})$. Finally, the combined organic layers were washed with brine $(50 \mathrm{~mL})$, dried over anhydrous $\mathrm{MgSO}_{4}$ and filtered. After removal of the solvent, a yellow solid was obtained (5.3 g, 72\%): TLC: $R_{f}(20 \%$ hexane in DCM) 0.75 ; ${ }^{1} \mathrm{H}$ NMR (400 MHz, $\left.\mathrm{CDCl}_{3}\right) \delta(\mathrm{ppm}): 7.93(2 \mathrm{H}, \mathrm{d}, J=6.8 \mathrm{~Hz}), 5.16(1 \mathrm{H}, \mathrm{s}), 4.36(2 \mathrm{H}$, $\mathrm{qd}, J=7.2 \mathrm{~Hz}), 1.35(3 \mathrm{H}, \mathrm{t}, J=7.2 \mathrm{~Hz}) ;{ }^{13} \mathrm{C}\left\{{ }^{1} \mathrm{H}\right\} \mathrm{NMR}\left(101 \mathrm{MHz}, \mathrm{CDCl}_{3}\right) \delta(\mathrm{ppm}): 162.1$, $161.6(\mathrm{~d}, J=6.7 \mathrm{~Hz}), 159.1(\mathrm{~d}, J=6.7 \mathrm{~Hz}), 114.6(\mathrm{t}, J=18.3 \mathrm{~Hz}), 112.4,108.4$ (d, $J=24.3$ $\mathrm{Hz}$ ), 64.6, 31.9, 13.9; ${ }^{19} \mathrm{~F}$ NMR (375 MHz, $\left.\mathrm{CDCl}_{3}\right) \delta(\mathrm{ppm})$ : -106.8 (2F, d, $J=6.8 \mathrm{~Hz}$ ).

2-(2,6-Difluoro-4-nitrophenyl)acetonitrile (15). A modified method was followed to synthesize compound 15. ${ }^{28}$ Compound 18 (5.3 g, $\left.19.5 \mathrm{mmol}\right)$ was dissolved in a mixture of water/acetic $(22.5 \mathrm{~mL} / 7.5 \mathrm{~mL})$ and then $37 \% \mathrm{HCl}(4 \mathrm{~mL})$ was added. The solution was stirred at $100^{\circ} \mathrm{C}$ for $12 \mathrm{~h}$. After quenching with saturated $\mathrm{NaHCO}_{3}(100$ $\mathrm{mL})$, the solution was extracted three times with diethyl ether $(40 \mathrm{~mL})$. The combined organics layers were collected and washed with brine $(50 \mathrm{~mL})$, dried over anhydrous $\mathrm{MgSO}_{4}$ and filtered. Finally, the solvent was removed under vacuum. The product was purified by column chromatography (silica gel, DCM). The appropriate fractions were collected and the solvent was removed to give a yellow solid (1.5 g, 39\%): mp 85-86 ${ }^{\circ} \mathrm{C}$; TLC: $R_{f}\left(20 \%\right.$ hexane in DCM) $0.75 ;{ }^{1} \mathrm{H} \mathrm{NMR}\left(400 \mathrm{MHz}, \mathrm{CDCl}_{3}\right) \delta$ (ppm): 7.91 $(2 \mathrm{H}, \mathrm{d}, J=6.8 \mathrm{~Hz}), 3.83(2 \mathrm{H}, \mathrm{s}) ;{ }^{13} \mathrm{C}\left\{{ }^{1} \mathrm{H}\right\} \mathrm{NMR}\left(101 \mathrm{MHz}, \mathrm{CDCl}_{3}\right) \delta(\mathrm{ppm}): 159.8$ (d, 
$J=254 \mathrm{~Hz}), 149.0$ (d, J=8.6 Hz), 130.6 (d, J=3.3 Hz), 125.0 (d, $J=15.8 \mathrm{~Hz}), 120.1$ (d, $J=3.9 \mathrm{~Hz}), 115.5,111.7(\mathrm{~d}, J=26.3 \mathrm{~Hz}), 18.1$ (d, $J=4.9 \mathrm{~Hz}) .{ }^{19} \mathrm{~F}$ NMR $(375 \mathrm{MHz}$, $\left.\mathrm{CDCl}_{3}\right) \delta(\mathrm{ppm}):-107.8(1 \mathrm{~F}, \mathrm{~d}, J=6.8 \mathrm{~Hz}) ; \mathrm{MS}(\mathrm{EI}): \mathrm{m} / z 198\left(\mathrm{M}^{+}, 100\right), 152(66), 125$ (53) (calcd mass for $\mathrm{C}_{8} \mathrm{H}_{4} \mathrm{~F}_{2} \mathrm{~N}_{2} \mathrm{O}_{2}[\mathrm{M}+\mathrm{H}]^{+}$: 198).

\section{Synthesis of model coumarin derivatives (3-9)}

7-(N,N-Diethylamino)-4-methyl-2-thiocoumarin (2). A modified method was followed to synthesize compound 2. ${ }^{29}$ Coumarin 1 (1.72 g, $\left.7.42 \mathrm{mmol}\right)$ and Lawesson's reagent $(1.65 \mathrm{~g}, 4.08 \mathrm{mmol})$ were dissolved in toluene $(40 \mathrm{~mL})$ and heated at $100^{\circ} \mathrm{C}$ for $12 \mathrm{~h}$. After evaporation under reduced pressure, the dark residue was purified by column chromatography (silica gel, DCM) to give an orange solid $(1.70 \mathrm{~g}, 92 \%)$ : TLC: $R_{f}$ (DCM) 0.50; ${ }^{1} \mathrm{H}$ NMR (400 MHz, $\left.\mathrm{CDCl}_{3}\right) \delta$ (ppm): 7.44 (1H, d, J=9.6 Hz), 6.93 (1H, br q, $J=0.8 \mathrm{~Hz}), 6.69-6.65(2 \mathrm{H}, \mathrm{m}), 3.43(4 \mathrm{H}, \mathrm{q}, J=7.2 \mathrm{~Hz}), 2.29(3 \mathrm{H}, \mathrm{d}, J=0.8 \mathrm{~Hz}), 1.24$ $(6 \mathrm{H}, \mathrm{t}, J=7.2 \mathrm{~Hz}) ;{ }^{13} \mathrm{C}\left\{{ }^{1} \mathrm{H}\right\} \mathrm{NMR}\left(101 \mathrm{~Hz}, \mathrm{CDCl}_{3}\right) \delta$ (ppm): 197.0, 158.9, 150.9, 146.2, 125.6, 123.6, 111.2, 110.1, 97.2, 44.9, 17.8, 12.4; HRMS (ESI-TOF) m/z: $[\mathrm{M}+\mathrm{H}]^{+}$ Calcd for $\mathrm{C}_{14} \mathrm{H}_{18} \mathrm{NOS} 248.1109$; Found 248.1099.

2-(Dicyanomethylene)-7-(N,N-diethylamino)-4-methylcoumarin (3). A modified method was followed to synthesize compound $3{ }^{29}$ Silver nitrate $(172 \mathrm{mg}, 1.02 \mathrm{mmol})$ was added to a solution of 2 (100 mg, $0.40 \mathrm{mmol})$, malononitrile (40 mg, $0.61 \mathrm{mmol})$ and triethylamine $(200 \mu \mathrm{L}, 1.41 \mathrm{mmol})$ in dry ACN $(20 \mathrm{~mL})$ under an argon atmosphere. The reaction mixture was stirred for $3 \mathrm{~h}$ in the dark at room temperature and then concentrated under reduced pressure, The crude product was purified by column chromatography (silica gel, 50-100\% of DCM in hexane) to give a yellow solid (97.6 $\mathrm{mg}, 86 \%$ ); mp 187-189 ${ }^{\circ} \mathrm{C}$; TLC: $R_{f}(\mathrm{DCM}) 0.53 ;{ }^{1} \mathrm{H} \mathrm{NMR}\left(400 \mathrm{MHz}, \mathrm{CDCl}_{3}\right) \delta(\mathrm{ppm})$ : $7.42(1 \mathrm{H}, \mathrm{d}, J=9.2 \mathrm{~Hz}), 6.68(1 \mathrm{H}, \mathrm{dd}, J=9.2 \mathrm{~Hz}, J=2.6 \mathrm{~Hz}), 6.59-6.57(2 \mathrm{H}, \mathrm{m}), 3.45$ (4H, q, $J=7.2 \mathrm{~Hz}), 2.41(3 \mathrm{H}, \mathrm{d}, J=0.7 \mathrm{~Hz}), 1.24(6 \mathrm{H}, \mathrm{t}, J=7.2 \mathrm{~Hz}) ;{ }^{13} \mathrm{C}\left\{{ }^{1} \mathrm{H}\right\} \mathrm{NMR}(101 \mathrm{~Hz}$, $\left.\mathrm{CDCl}_{3}\right) \delta(\mathrm{ppm}): 171.9,154.9,151.6,149.9,126.0,115.2,114.4,110.4,110.0,108.6$,

97.1, 44.9, 18.6, 12.5; HRMS (ESI-TOF) m/z: $[\mathrm{M}+\mathrm{H}]^{+}$Calcd for $\mathrm{C}_{17} \mathrm{H}_{18} \mathrm{~N}_{3} \mathrm{O} 280.1450$; Found 280.1440.

General procedure for the synthesis of coumarin derivatives 4-9: Compound 2 (150 mg, $0.61 \mathrm{mmol})$ was added to a solution of the corresponding arylacetonitrile derivative (1015) (0.92 mmol, 1.5 mol equiv.) in anhydrous $\mathrm{ACN}(10 \mathrm{~mL})$ under an Ar atmosphere and protected from light. After addition of triethylamine (126 $\mu \mathrm{L}, 0.92 \mathrm{mmol}, 1.5 \mathrm{~mol}$ equiv.) the reaction mixture, which acquired an intense dark colour, was stirred for $2 \mathrm{~h}$. 
Then, silver nitrate (226 mg, $1.34 \mathrm{mmol}, 2.2 \mathrm{~mol}$ equiv.) was added and the reaction mixture was stirred at room temperature for 1-2 $\mathrm{h}$ under an Ar atmosphere and protected from light. The crude product was evaporated under reduced pressure and purified by column chromatography (silica gel, in most cases the following gradient was used: 0$100 \%$ DCM in hexane) to give the desired coumarin derivative (4-9).

2-(Cyano(4-nitrophenyl)methylene)-7-(N,N-diethylamino)-4-methylcoumarin (4). Dark red solid (91 mg, 40\%): mp 228-230 ${ }^{\circ} \mathrm{C}$; TLC: $R_{f}$ (DCM) 0.8; ${ }^{1} \mathrm{H}$ NMR (400 MHz, $\left.\mathrm{CDCl}_{3}\right) \delta(\mathrm{ppm})$ : (major rotamer) $8.25(2 \mathrm{H}, \mathrm{d}, J=9.2 \mathrm{~Hz}), 7.99(2 \mathrm{H}, \mathrm{d}, J=9.2 \mathrm{~Hz}), 7.34$ $(1 \mathrm{H}, \mathrm{d}, J=8.8 \mathrm{~Hz}), 6.77(1 \mathrm{H}$, br q), $6.60(1 \mathrm{H}, \mathrm{dd}, J=8.8 \mathrm{~Hz}, J=2.4 \mathrm{~Hz}), 6.43(1 \mathrm{H}, \mathrm{d}$, $J=2.4 \mathrm{~Hz}), 3.45(4 \mathrm{H}, \mathrm{q}, J=7.2 \mathrm{~Hz}), 2.36(3 \mathrm{H}$, br d, $J=1.2 \mathrm{~Hz}), 1.24(6 \mathrm{H}, \mathrm{t}, J=7.2 \mathrm{~Hz})$; ${ }^{13} \mathrm{C}\left\{{ }^{1} \mathrm{H}\right\} \mathrm{NMR}\left(101 \mathrm{~Hz}, \mathrm{CDCl}_{3}\right) \delta(\mathrm{ppm})$ : (major rotamer) 162.9, 154.3, 150.7, 144.7, 144.3, 140.4, 126.8, 125.5, 123.8, 120.1, 112.3, 110.1, 109.3, 96.8, 82.1, 44.7, 18.4, 12.5; HRMS (ESI-TOF) m/z: $[\mathrm{M}+\mathrm{H}]^{+}$Calcd for $\mathrm{C}_{22} \mathrm{H}_{22} \mathrm{~N}_{3} \mathrm{O}_{3}$ 376.1656; Found 376.1658; Analytical HPLC (50 to $100 \% \mathrm{~B}$ in $30 \mathrm{~min}: \mathrm{R}_{\mathrm{t}}=26.1 \mathrm{~min}$ ).

2-(Cyano(2-cyano-4-nitrophenyl)methylene)-7-(N,N-diethylamino)-4-methylcoumarin

(5). Dark red solid (132 mg, 54\%): mp 230-234 ${ }^{\circ} \mathrm{C}$ (decomp.); TLC: $R_{f}(\mathrm{DCM}) 0.45 ;{ }^{1} \mathrm{H}$ NMR (400 MHz, $\left.\mathrm{CDCl}_{3}\right) \delta(\mathrm{ppm})$ : (major rotamer) $8.58(1 \mathrm{H}, \mathrm{d}, J=2.4 \mathrm{~Hz}), 8.41(1 \mathrm{H}$, $\mathrm{dd}, J=8.8 \mathrm{~Hz}, J=2.4 \mathrm{~Hz}), 7.79(1 \mathrm{H}, \mathrm{d}, J=8.8 \mathrm{~Hz}), 7.36(1 \mathrm{H}, \mathrm{d}, J=9.2 \mathrm{~Hz}), 6.73(1 \mathrm{H}, \mathrm{br}$ q, $J=1.2 \mathrm{~Hz}), 6.59(1 \mathrm{H}, \mathrm{dd}, J=9.2 \mathrm{~Hz}, J=2.6 \mathrm{~Hz}), 6.31(1 \mathrm{H}, \mathrm{d}, J=2.6 \mathrm{~Hz}), 3.41(4 \mathrm{H}, \mathrm{q}$, $J=7.2 \mathrm{~Hz}), 2.39(3 \mathrm{H}, \mathrm{d}, J=0.8 \mathrm{~Hz}), 1.20(6 \mathrm{H}, \mathrm{t}, J=7.2 \mathrm{~Hz}) ;{ }^{13} \mathrm{C}\left\{{ }^{1} \mathrm{H}\right\} \mathrm{NMR}(101 \mathrm{MHz}$, $\left.\mathrm{CDCl}_{3}\right) \delta(\mathrm{ppm})$ : (major rotamer) 164.1, 154.0, 151.0, 146.9, 145.2, 143.6, 132.4, 131.0, 129.2, 127.2, 125.8, 119.4, 116.6, 112.6, 110.9, 110.1, 109.6, 97.1, 44.8, 18.5, 12.4; HRMS (ESI-TOF) m/z: $[\mathrm{M}+\mathrm{H}]^{+}$Calcd for $\mathrm{C}_{23} \mathrm{H}_{21} \mathrm{~N}_{4} \mathrm{O}_{3}$ 401.1608; Found 401.1610; Analytical HPLC (50 to $100 \%$ B in 30 min: $R_{t}=19.9$ min).

2-(Cyano(2,4-dinitrophenyl)methylene)-7-(N,N-diethylamino)-4-methylcoumarin (6). Dark violet solid (175 mg, 68\%): mp 208-209 ${ }^{\circ} \mathrm{C}$; TLC: $R_{f}$ (DCM) 0.56; ${ }^{1} \mathrm{H}$ NMR (400 $\left.\mathrm{MHz} \mathrm{CDCl}_{3}\right) \delta(\mathrm{ppm}): 8.75(1 \mathrm{H}, \mathrm{d}, J=2.4 \mathrm{~Hz}), 8.38(1 \mathrm{H}, \mathrm{dd}, J=8.8 \mathrm{~Hz}, J=2.4 \mathrm{~Hz}), 7.86$ $(1 \mathrm{H}, \mathrm{d}, J=8.8 \mathrm{~Hz}), 7.33(1 \mathrm{H}, \mathrm{d}, J=8.8 \mathrm{~Hz}), 6.70(1 \mathrm{H}$, br q), $6.58(1 \mathrm{H}, \mathrm{dd}, J=8.8 \mathrm{~Hz}$, $J=2.4 \mathrm{~Hz}), 6.23(1 \mathrm{H}, \mathrm{d}, J=2.4 \mathrm{~Hz}), 3.42(4 \mathrm{H}, \mathrm{q}, J=7.2 \mathrm{~Hz}), 2.37(3 \mathrm{H}, \mathrm{br} \mathrm{s}), 1.24(6 \mathrm{H}, \mathrm{t}$, $J=7.2 \mathrm{~Hz}) ;{ }^{13} \mathrm{C}\left\{{ }^{1} \mathrm{H}\right\} \mathrm{NMR}\left(101 \mathrm{~Hz}, \mathrm{CDCl}_{3}\right) \delta(\mathrm{ppm}): 163.7,153.9,151.0,147.3,146.9$, 144.9, 134.2, 131.7, 126.6, 125.7, 121.0, 119.4, 111.0, 110.0, 109.6, 96.9, 44.9, 18.5, 12.4; HRMS (ESI-TOF) m/z: $[\mathrm{M}+\mathrm{H}]^{+}$Calcd for $\mathrm{C}_{22} \mathrm{H}_{21} \mathrm{~N}_{4} \mathrm{O}_{5}$ 421.1506; Found 421.1506; Analytical HPLC (50 to $100 \%$ B in 30 min: $R_{t}=21.8 \mathrm{~min}$ ). 
2-(Cyano(2,4,6-trinitrophenyl)methylene)-7-(N,N-diethylamino)-4-methylcoumarin (7).

Dark green solid (50 mg from $100 \mathrm{mg}$ of 2, 27\%); mp 223-224 ${ }^{\circ} \mathrm{C}$; TLC: $R_{f}(2 \% \mathrm{MeOH}$ in DCM) 0.8; ${ }^{1} \mathrm{H}$ NMR (400 MHz, $\left.\mathrm{CDCl}_{3}\right) \delta(\mathrm{ppm}): 8.85(2 \mathrm{H}, \mathrm{s}), 7.37(1 \mathrm{H}, \mathrm{d}, J=9.2$ $\mathrm{Hz}), 6.71(1 \mathrm{H}, \mathrm{br} \mathrm{s}), 6.61(1 \mathrm{H}, \mathrm{dd}, J=9.2 \mathrm{~Hz}, J=2.4 \mathrm{~Hz}), 6.16(1 \mathrm{H}, \mathrm{d}, J=2.4 \mathrm{~Hz}), 3.41$ $(4 \mathrm{H}, \mathrm{q}, J=7.2 \mathrm{~Hz}), 2.39\left(3 \mathrm{H}\right.$, br s), $1.23(6 \mathrm{H}, \mathrm{t}, J=7.2 \mathrm{~Hz}) ;{ }^{13} \mathrm{C}\left\{{ }^{1} \mathrm{H}\right\} \mathrm{NMR}(101 \mathrm{~Hz}$, $\left.\mathrm{CDCl}_{3}\right) \delta(\mathrm{ppm}): 164.6,153.8,151.2,149.7,148.5,144.8,128.0,126.0,123.2,116.4$, 110.2, 110.1, 110.0, 96.7, 71.1, 45.0, 18.6, 12.4; HRMS (ESI-TOF) m/z: $[\mathrm{M}+\mathrm{H}]^{+}$Calcd for $\mathrm{C}_{22} \mathrm{H}_{20} \mathrm{~N}_{5} \mathrm{O}_{7} 466.1357$; Found 466.1362; Analytical HPLC (50 to 100\% B in 30 min: $\left.\mathrm{R}_{\mathrm{t}}=19.7 \mathrm{~min}\right)$.

2-(Cyano(2-fluoro-4-nitrophenyl)methylene)-7-(N,N-diethylamino)-4-methylcoumarin (8). Dark red solid (101 mg, 42\%): mp 159-160 ${ }^{\circ} \mathrm{C}$; TLC: $R_{f}(\mathrm{DCM}) 0.53 ;{ }^{1} \mathrm{H}$ NMR (400 $\left.\mathrm{MHz}, \mathrm{CDCl}_{3}\right) \delta(\mathrm{ppm})$ : (major rotamer) $8.07(1 \mathrm{H}, \mathrm{ddd}, J=8.6 \mathrm{~Hz}, J=2.4 \mathrm{~Hz}, J=0.8 \mathrm{~Hz}$ ), $8.01(1 \mathrm{H}, \mathrm{dd}, J=10.0 \mathrm{~Hz}, J=2.4 \mathrm{~Hz}), 7.73(1 \mathrm{H}, \mathrm{dd}, J=8.6 \mathrm{~Hz}, J=7.2 \mathrm{~Hz}), 7.32(1 \mathrm{H}, \mathrm{d}$, $J=8.9 \mathrm{~Hz}), 6.72(1 \mathrm{H}$, br q, $J=1.2 \mathrm{~Hz}), 6.56(1 \mathrm{H}, \mathrm{dd}, J=8.9 \mathrm{~Hz}, J=2.5 \mathrm{~Hz}), 6.24(1 \mathrm{H}, \mathrm{d}$, $J=2.5 \mathrm{~Hz}), 3.39(4 \mathrm{H}, \mathrm{q}, J=7.2 \mathrm{~Hz}), 2.34(3 \mathrm{H}, \mathrm{d}, J=1.2 \mathrm{~Hz}), 1.19(6 \mathrm{H}, \mathrm{t}, J=7.2 \mathrm{~Hz})$; ${ }^{13} \mathrm{C}\left\{{ }^{1} \mathrm{H}\right\} \mathrm{NMR}\left(101 \mathrm{MHz}, \mathrm{CDCl}_{3}\right) \delta(\mathrm{ppm})$ : (major rotamer) 163.4, $158.9(\mathrm{~d}, J=256 \mathrm{~Hz})$, 154.4, 150.6, 146.7 (d, J=8.5 Hz), 144.50, 130.9 (d, J=3.4 Hz), 128.5 (d, J=14.3 Hz), 125.4, 119.5, 119.2 (d, J=3.4Hz), 112.0, 111.8, 111.3, 110.0, 109.0, 96.9, 74.6, 44.6, 18.3, 12.5; ${ }^{19} \mathrm{~F}$ NMR (375 MHz, $\left.\mathrm{CDCl}_{3}\right) \delta(\mathrm{ppm})$ : (major rotamer) -104.3 (1F, dd, $J=10.0 \mathrm{~Hz}, J=7.2 \mathrm{~Hz}$ ); HRMS (ESI-TOF) $\mathrm{m} / \mathrm{z}$ : $[\mathrm{M}+\mathrm{H}]^{+}$Calcd for $\mathrm{C}_{22} \mathrm{H}_{21} \mathrm{FN}_{3} \mathrm{O}_{3}$ 394.1561; Found 394.1566; Analytical HPLC (50 to 100\% B in $30 \mathrm{~min}: \mathrm{R}_{\mathrm{t}}=23.8 \mathrm{~min}$ ). 2-(Cyano(2,6-difluoro-4-nitrophenyl)methylene)-7-(N,N-diethylamino)-4-

methylcoumarin (9). Dark red solid (137 mg, 55\%): mp 168-169 ${ }^{\circ} \mathrm{C}$; TLC: $R_{f}(\mathrm{DCM})$ 0.64; ${ }^{1} \mathrm{H}$ NMR (400 MHz, $\left.\mathrm{CDCl}_{3}\right) \delta$ (ppm): (major rotamer) $7.87(2 \mathrm{H}, \mathrm{d}, J=7.2 \mathrm{~Hz}$ ), $7.33(1 \mathrm{H}, \mathrm{d}, J=8.8 \mathrm{~Hz}), 6.73(1 \mathrm{H}$, br q, $J=1.2 \mathrm{~Hz}),, 6.56(1 \mathrm{H}, \mathrm{dd}, J=8.8 \mathrm{~Hz}, J=2.4 \mathrm{~Hz})$, $6.18(1 \mathrm{H}, \mathrm{d}, J=2.4 \mathrm{~Hz}), 3.38(4 \mathrm{H}, \mathrm{q}, J=7.2 \mathrm{~Hz}), 2.35(3 \mathrm{H}, \mathrm{d}, J=1.2 \mathrm{~Hz}), 1.18$ (6H, t, $J=7.2 \mathrm{~Hz}) ;{ }^{13} \mathrm{C}\left\{{ }^{1} \mathrm{H}\right\} \mathrm{NMR}\left(101 \mathrm{MHz}, \mathrm{CDCl}_{3}\right) \delta$ (ppm): (major rotamer) 164.4, 160.0 (dd, $J=256 \mathrm{~Hz}, J=7.3 \mathrm{~Hz}), 154.6,150.6,147.1$ (t, $J=11 \mathrm{~Hz}), 144.9,125.5,118.3,117.7$ (t, $J=19 \mathrm{~Hz}), 110.7$, 109.8, 109.0, 107.9, 107.6, 96.9, 64.7, 44.6, 18.3, 12.4; ${ }^{19} \mathrm{~F}$ NMR $\left(375 \mathrm{MHz}, \mathrm{CDCl}_{3}\right) \delta(\mathrm{ppm}):-102.7(2 \mathrm{~F}, \mathrm{~d}, J=7.2 \mathrm{~Hz})$; HRMS (ESI-TOF) m/z: $[\mathrm{M}+\mathrm{H}]^{+}$ Calcd for $\mathrm{C}_{22} \mathrm{H}_{20} \mathrm{~F}_{2} \mathrm{~N}_{3} \mathrm{O}_{3}$ 412.1467; Found 412.1470; Analytical HPLC (50 to 100\% B in 30 min: $\left.R_{t}=23.7 \min \right)$.

\section{Synthesis of coumarin-caged derivatives of benzoic acid (25-28).}


4-(Benzoyloxymethyl)-7-(N,N-diethylamino)-2-thiocoumarin (24). A solution of $\mathrm{HCl}$ in 1,4-dioxane (4 M, $2.5 \mathrm{~mL}, 10 \mathrm{mmol})$ was added to $\mathbf{2 2}^{21}$ (1.5 g, $\left.4.92 \mathrm{mmol}\right)$ in absolute ethanol $(120 \mathrm{~mL})$. The reaction mixture was heated at $90^{\circ} \mathrm{C}$ for $20 \mathrm{~h}$ and evaporated under vacuum. The resulting orange solid was dissolved in dry DCM $(25 \mathrm{~mL})$ at $0^{\circ} \mathrm{C}$ under an Ar atmosphere together with 1-ethyl-3-(3-dimethylaminopropyl)carbodiimide hydrochloride (0.94 g, $4.9 \mathrm{mmol})$, DMAP (0.60 g, $4.9 \mathrm{mmol})$ and benzoic acid (0.72 g, $5.9 \mathrm{mmol}$ ). After $10 \mathrm{~min}$ at $0^{\circ} \mathrm{C}$, the reaction mixture was stirred at room temperature for $18 \mathrm{~h}$ in the dark and under Ar. Subsequently, the organic solution was washed with aqueous saturated $\mathrm{NaHCO}_{3}(1 \times 20 \mathrm{~mL})$, aqueous $10 \%$ ammonium chloride $(2$ x 25 $\mathrm{mL})$, water $(1 \times 25 \mathrm{~mL})$ and dried over anhydrous $\mathrm{Na}_{2} \mathrm{SO}_{4}$. After purification by column chromatography (silica gel, DCM), an orange solid was obtained (1.3 g, 72\%): TLC: $R_{f}$ (DCM) 0.8; ${ }^{1} \mathrm{H}$ NMR (400 MHz, $\left.\mathrm{CDCl}_{3}\right) \delta(\mathrm{ppm}): 8.11(2 \mathrm{H}, \mathrm{m}, H A r), 7.64-7.60(1 \mathrm{H}$, m), 7.51-7.43 (3H, m, HAr), 7.15 (1H, t, H3, J=1.2 Hz), 6.71-6.67 (2H, m, HAr), 5.43 $\left(2 \mathrm{H}, \mathrm{d}, \mathrm{CH}_{2}, \mathrm{~J}=1.2 \mathrm{~Hz}\right), 3.44\left(4 \mathrm{H}, \mathrm{q}, \mathrm{CH}_{2} \mathrm{Et}, \mathrm{J}=7.2 \mathrm{~Hz}\right), 1.23\left(6 \mathrm{H}, \mathrm{t}, \mathrm{CH}_{3} \mathrm{Et}, \mathrm{J} 7.2 \mathrm{~Hz}\right)$; ${ }^{13} \mathrm{C}\left\{{ }^{1} \mathrm{H}\right\} \mathrm{NMR}\left(101 \mathrm{MHz}, \mathrm{CDCl}_{3}\right) \delta(\mathrm{ppm}): 197.3,166.0,159.2,151.2,142.1,138.8$, 130.0, 129.2, 128.7, 124.7, 120.9, 110.5, 108.4, 97.6, 61.7, 45.1, 12.6; HRMS (ESITOF) m/z: $[\mathrm{M}+\mathrm{H}]^{+}$Calcd for $\mathrm{C}_{21} \mathrm{H}_{22} \mathrm{NO}_{3} \mathrm{~S}$ 368.1320; Found 368.1312.

General procedure for the synthesis of coumarin derivatives 25-27

Compound 24 (150 mg, $0.41 \mathrm{mmol}$ ) and the corresponding arylacetonitrile derivative (10, 12 or 13) (0.61 mmol, $1.5 \mathrm{~mol}$ equiv. for 10 and 12; $0.82 \mathrm{mmol}, 2 \mathrm{~mol}$ equiv. for 13) were dissolved in anhydrous $\operatorname{ACN}(20 \mathrm{~mL})(\mathbf{2 5}, \mathbf{2 6})$ or in a $1: 1$ mixture of anhydrous DCM/ACN (20 mL) (27) under an Ar atmosphere and protected from light. After addition of triethylamine (25, 26: $86 \mu \mathrm{L}, 0.61$ mmol, 1.5 mol equiv.; 27: $113 \mu \mathrm{L}$, $0.82 \mathrm{mmol}, 2 \mathrm{~mol}$ equiv.), the reaction mixture, which acquired an intense dark colour, was stirred for $2 \mathrm{~h}$. Then, silver nitrate $(153 \mathrm{mg}, 0.9 \mathrm{mmol}, 2.2 \mathrm{~mol}$ equiv.) was added and the reaction mixture was stirred at room temperature for $2 \mathrm{~h}$ under an $\mathrm{Ar}$ atmosphere and protected from light. The crude product was evaporated under reduced pressure and purified by column chromatography (silica gel, 0-100\% DCM in hexane) to give the desired coumarin derivative (25-27).

4-(Benzoyloxymethyl)-2-(cyano(4-nitrophenyl)methylene)-7-( $N, N$ -

diethylamino)coumarin (25). Red solid (140 mg, 69\%): mp 219-222 ${ }^{\circ} \mathrm{C}$ (decomp.); TLC: $\mathrm{R}_{\mathrm{f}}(\mathrm{DCM})$ 0.44; ${ }^{1} \mathrm{H}$ NMR (400 MHz, $\left.\mathrm{CDCl}_{3}\right) \delta$ (ppm): (major rotamer) $8.27(2 \mathrm{H}$, m), $8.12(2 \mathrm{H}, \mathrm{m}), 7.99(2 \mathrm{H}, \mathrm{m}), 7.63-7.57(1 \mathrm{H}, \mathrm{m}), 7.51-7.46(2 \mathrm{H}, \mathrm{m}), 7.36(1 \mathrm{H}, \mathrm{d}, J=$ 
$8.8 \mathrm{~Hz}), 7.08(1 \mathrm{H}$, br t), $6.59(1 \mathrm{H}, \mathrm{dd}, J=8.8 \mathrm{~Hz}, J=2.4 \mathrm{~Hz}), 6.44(1 \mathrm{H}, \mathrm{d}, J=2.4 \mathrm{~Hz}), 5.42$ $(2 \mathrm{H}, \mathrm{d}, J=1.2 \mathrm{~Hz}), 3.45(4 \mathrm{H}, \mathrm{q}, J=7.2 \mathrm{~Hz}), 1.24(6 \mathrm{H}, \mathrm{t}, J=7.2 \mathrm{~Hz}) ;{ }^{13} \mathrm{C}\left\{{ }^{1} \mathrm{H}\right\} \mathrm{NMR}(101$ $\left.\mathrm{MHz}, \mathrm{CDCl}_{3}\right) \delta(\mathrm{ppm})$ : (major rotamer) 166.0, 162.1, 154.5, 150.8, 145.2, 140.5, 139.8, 133.6, 129.8, 129.2, 128.7, 127.2, 124.8, 123.9, 119.4, 111.4, 109.4, 107.3, 97.1, 84.7, 62.3, 44.7, 12.5; HRMS (ESI-TOF) m/z: $[\mathrm{M}+\mathrm{H}]^{+}$Calcd for $\mathrm{C}_{29} \mathrm{H}_{26} \mathrm{~N}_{3} \mathrm{O}_{5}$ 496.1867; Found 496.1857; Analytical HPLC (50 to $100 \%$ B in $30 \mathrm{~min}: \mathrm{R}_{\mathrm{t}}=27.9 \mathrm{~min}$ ).

4-(Benzoyloxymethyl)-7-(N,N-diethylamino)-2-(cyano(2,4-dinitrophenyl)methylene)coumarin (26). Dark violet solid (90 mg, 41\%): mp 220-223 ${ }^{\circ} \mathrm{C}$ (decomp.); TLC: $R_{f}$ (DCM) 0.5; ${ }^{1} \mathrm{H}$ NMR (400 MHz, $\left.\mathrm{CDCl}_{3}\right) \delta(\mathrm{ppm}): 8.77(1 \mathrm{H}, \mathrm{d}, J=2.4 \mathrm{~Hz}), 8.41(1 \mathrm{H}, \mathrm{dd}$, $J=8.8 \mathrm{~Hz}, J=2.4 \mathrm{~Hz}), 8.12(2 \mathrm{H}, \mathrm{m}), 7.89(1 \mathrm{H}, \mathrm{d}, J=8.8 \mathrm{~Hz}), 7.62(1 \mathrm{H}, \mathrm{m}), 7.50(2 \mathrm{H}, \mathrm{m})$, 7.34 (1H, d, H5), $7.01(1 \mathrm{H}, \mathrm{br}$ t), $6.57(1 \mathrm{H}, \mathrm{dd}, J=8.8 \mathrm{~Hz}, J=2.4 \mathrm{~Hz}), 6.26(1 \mathrm{H}, \mathrm{d}, J=2.4$ $\mathrm{Hz}), 5.43(2 \mathrm{H}, \mathrm{d}, J=0.8 \mathrm{~Hz}), 3.42(4 \mathrm{H}, \mathrm{q}, J=7.2 \mathrm{~Hz}), 1.24(6 \mathrm{H}, \mathrm{t}, J=7.2 \mathrm{~Hz})$; ${ }^{13} \mathrm{C}\left\{{ }^{1} \mathrm{H}\right\} \mathrm{NMR}\left(101 \mathrm{MHz}, \mathrm{CDCl}_{3}\right) \delta(\mathrm{ppm}): 165.9,163.0,154.1,151.1,147.6,145.4$, $142.8,133.6,131.9$, 129.8, 129.1, 128.7, 126.7, 124.9, 120.9, 118.7, 109.8, 109.4, 107.1, 97.2, 79.4, 62.1, 45.0, 12.4; HRMS (ESI-TOF) m/z: $[\mathrm{M}+\mathrm{H}]^{+}$Calcd for $\mathrm{C}_{29} \mathrm{H}_{25} \mathrm{~N}_{4} \mathrm{O}_{7}$ 541.1718; Found 541.1718; Analytical HPLC (50 to $100 \% \mathrm{~B}$ in 30 min: $\mathrm{R}_{\mathrm{t}}$ $=23.2 \mathrm{~min}$ ).

4-(Benzoyloxymethyl)-2-(cyano(2,4,6-trinitrophenyl)methylene)-7-(N,N-

diethylamino)coumarin (27). Dark green solid (19 mg, 8\%): $\mathrm{mp} 222-224{ }^{\circ} \mathrm{C}$ (decomp.); TLC: $R_{f}(\mathrm{DCM}) 0.4 ;{ }^{1} \mathrm{H} \mathrm{NMR}\left(400 \mathrm{MHz}, \mathrm{CDCl}_{3}\right) \delta(\mathrm{ppm}): 8.89(2 \mathrm{H}, \mathrm{s}), 8.13(2 \mathrm{H}, \mathrm{m})$, $7.62(1 \mathrm{H}, \mathrm{m}), 7.50(2 \mathrm{H}, \mathrm{m}), 7.36(1 \mathrm{H}, \mathrm{d}, J=9.2 \mathrm{~Hz}), 7.03(1 \mathrm{H}, \mathrm{br} \mathrm{t}), 6.61(1 \mathrm{H}, \mathrm{dd}, J=9.2$ $\mathrm{Hz}, J=2.4 \mathrm{~Hz}), 6.18(1 \mathrm{H}, \mathrm{d}, J=2.4 \mathrm{~Hz}), 5.45(2 \mathrm{H}$, br d, $J=0.8 \mathrm{~Hz}), 3.41(4 \mathrm{H}, \mathrm{q}, J=7.2$ $\mathrm{Hz}), 1.23(6 \mathrm{H}, \mathrm{t}, J=7.2 \mathrm{~Hz}) ;{ }^{13} \mathrm{C}\left\{{ }^{1} \mathrm{H}\right\} \mathrm{NMR}\left(101 \mathrm{MHz}, \mathrm{CDCl}_{3}\right) \delta(\mathrm{ppm}): 165.8,164.1$, $154.0,151.2$, 149.9, 145.4, 144.2, 133.7, 129.9, 129.0, 128.7, 127.4, 125.1, 123.2, 115.9, 110.2, 108.3, 107.2, 97.0, 73.4, 61.9, 45.0, 12.4; HRMS (ESI-TOF) m/z: [M+H] ${ }^{+}$ Calcd for $\mathrm{C}_{29} \mathrm{H}_{24} \mathrm{~N}_{5} \mathrm{O}_{9} 586.1569$; Found 586.1560; Analytical HPLC (50 to 100\% B in $30 \min : \mathrm{R}_{\mathrm{t}}=20.9 \mathrm{~min}$ ).

4-(Benzoyloxyeth-1-yl)-7-(N,N-diethylamino)-2-(cyano(4-

nitrophenyl)methylene)coumarin (28). A solution of 4-(benzoyloxymethyl)-7-( $N, N$ diethylamino)-4-(1-hydroxyeth-1-yl)-2-thiocoumarin ${ }^{21}(75 \mathrm{mg}, 0.20 \mathrm{mmol}$ ) was added to a solution of 2-nitrophenylacetonitrile $(95.5 \mathrm{mg}, 0.59 \mathrm{mmol})$ and $\mathrm{NEt}_{3}(82 \mu \mathrm{L}, 0.59$ $\mathrm{mmol})$ in a 1:1 (v/v) mixture of anhydrous ACN and DCM (4 mL) under an Ar atmosphere. After stirring for $2.5 \mathrm{~h}$ at room temperature in the dark, silver nitrate $(73.5$ 
$\mathrm{mg}, 0.43 \mathrm{mmol}$ ) was added and the reaction mixture was stirred for additional $1.5 \mathrm{~h}$. After evaporation under reduced pressure, the crude product was purified by column chromatography (silica gel, hexane/AcOEt 6:4) to give a dark red solid (69 mg, 69\%); mp 219-221 ${ }^{\circ} \mathrm{C}$ (decomp.); TLC: $R_{f}\left(2 \% \mathrm{MeOH}\right.$ in DCM) 0.90; ${ }^{1} \mathrm{H}$ NMR (400 MHz, $\left.\mathrm{CDCl}_{3}\right) \delta(\mathrm{ppm})$ : (major rotamer) $8.26(2 \mathrm{H}, \mathrm{d}, J=9.0 \mathrm{~Hz}), 8.13(2 \mathrm{H}, \mathrm{m}, J=8.0 \mathrm{~Hz}), 7.98$ $(2 \mathrm{H}, \mathrm{d}, J=9.0 \mathrm{~Hz}), 7.61(1 \mathrm{H}, \mathrm{t}, J=7.2 \mathrm{~Hz}), 7.51-7.45(3 \mathrm{H}, \mathrm{m}), 7.08(1 \mathrm{H}, \mathrm{br} \mathrm{s}), 6.60(1 \mathrm{H}$, dd, $J=9.2 \mathrm{~Hz}, J=2.4 \mathrm{~Hz}), 6.44(1 \mathrm{H}, \mathrm{d}, J=2.4 \mathrm{~Hz}), 6.30(1 \mathrm{H}, \mathrm{q}, J=6.8 \mathrm{~Hz}), 3.45(4 \mathrm{H}, \mathrm{q}$, $J=7.2 \mathrm{~Hz}), 1.75(3 \mathrm{H}, \mathrm{s}, J=6.8 \mathrm{~Hz}), 1.24(6 \mathrm{H}, \mathrm{t}, J=7.2 \mathrm{~Hz}) ;{ }^{13} \mathrm{C}\left\{{ }^{1} \mathrm{H}\right\} \mathrm{NMR}(101 \mathrm{MHz}$, $\left.\mathrm{CDCl}_{3}\right) \delta(\mathrm{ppm})$ : (major rotamer) $163.7,160.5,152.9,148.8,144.8,143.2,138.1,131.6$, $127.9,127.6,126.8,126.7,125.2$, 123.0, 122.0, 117.7, 107.5, 107.2, 104.9, 95.3, 82.4, 66.3, 42.8, 19.0, 10.6; HRMS (ESI-TOF) m/z: $[\mathrm{M}+\mathrm{H}]^{+}$Calcd for $\mathrm{C}_{30} \mathrm{H}_{28} \mathrm{~N}_{3} \mathrm{O}_{5}$ 510.2023; Found 510.2019; Analytical HPLC (50 to $100 \%$ B in 30 min: $R_{t}=29.2 \mathrm{~min}$ ).

\section{Photophysical properties.}

Absorption spectra were recorded in a Varian Cary 500 UV-Vis-NIR spectrophotometer at $25^{\circ} \mathrm{C}$. Emission spectra were registered in a Photon Technology International (PTI) fluorimeter. Solutions for fluorescence quantum yield measurements were adjusted to concentrations such that the absorption was around 0.04 at the corresponding excitation wavelength. Fluorescence quantum yields, $\Phi_{\mathrm{F}}$, were calculated from equation (1):

$$
\Phi_{F}=\Phi_{F}^{s} \frac{A b s^{s}}{A b s} \frac{A}{A^{s}} \frac{n^{2}}{n_{s}^{2}}
$$

in which the superscript " $s$ " stands for standard samples, $A b s$ is the absorbance at the excitation wavelength $\left(\lambda_{\mathrm{Ex}}\right), A$ is the integrated area of the corresponding emission spectrum, and $n$ is the refractive index of the solvent used. ${ }^{22}$ The uncertainty in the experimental value of $\Phi_{\mathrm{F}}$ has been estimated to be $c a .10 \%$. The standard fluorophore used for the determination of the fluorescence quantum yield was either 7-diethylamino4-methylcoumarin (coumarin-1, $\lambda_{\mathrm{Ex}}=360 \mathrm{~nm}$ ) or fluorescein $\left(\lambda_{\mathrm{Ex}}=460 \mathrm{~nm}\right)$, with a reported absolute fluorescence quantum yield, $\Phi_{\mathrm{F}}$, of 0.73 (in ethanol) and 0.92 (in 0.1

$\mathrm{M}$ aqueous sodium hydroxide), respectively. ${ }^{23}$ All samples were measured in $1 \times 1 \mathrm{~cm}$ quartz cuvettes (Hellma).

\section{Irradiation experiments.}

Photolysis studies were performed at $37^{\circ} \mathrm{C}$ in a custom-built irradiation setup from Microbeam including a cuvette, thermostated cuvette holder and a mounted high power 
LED of $505 \mathrm{~nm}\left(100 \mathrm{~mW} / \mathrm{cm}^{2}\right)$. In a typical experiment, the irradiation samples contained the coumarin-caged model compound $(20 \mu \mathrm{M})$ in $\mathrm{MeOH}$. After irradiation, the samples were analyzed by reversed-phase HPLC-ESI MS in a Jupiter Proteo $\mathrm{C}_{18}$ column (250x4.6 mm, $90 \AA 4 \mu \mathrm{m}$, flow rate: $1 \mathrm{~mL} / \mathrm{min})$ using linear gradients of $0.1 \%$ formic acid in $\mathrm{H}_{2} \mathrm{O}(\mathrm{A})$ and $0.1 \%$ formic acid in $\mathrm{ACN}(\mathrm{B})$. The uncaging quantum yield for coumarin derivatives $\mathbf{2 5}$ and $\mathbf{2 8}$ was estimated as previously described. ${ }^{21}$ Briefly, 1.7 $\mathrm{mL}$ of $20 \mu \mathrm{M}$ solutions of the compounds were irradiated in a $1 \times 1 \mathrm{~cm}$ quarz cuvette at $505 \mathrm{~nm}$ using a LED lamp. The irradiance was determined as $1.05 \times 10^{-7}$ Einstein/s by actinometry with Aberchrome 540. ${ }^{21}$

\section{ASSOCIATED CONTENT}

\section{Supporting Information}

HPLC traces and UV-vis absorption and emission spectra of the compounds and results from the photolysis experiments. 1D NMR $\left(1 \mathrm{H},{ }^{13} \mathrm{C}\right.$ and $\left.{ }^{19} \mathrm{~F}\right), \mathrm{MS}$ and selected $2 \mathrm{D}$ NMR spectra. This material is available free of charge via the Internet at http://pubs.acs.org.

\section{AUTHOR INFORMATION}

Corresponding Author

*E-mail: vmarchan@ub.edu

\section{ACKNOWLEDGEMENTS}

This work was supported by funds from the Spanish Ministerio de Economía $y$ Competitividad (grants CTQ2014-52658-R and CTQ2015-65770-P) and the Generalitat de Catalunya (2014SGR187 and XRB). The authors acknowledge Dr. Francisco Cárdenas (Unitat d'RMN, CCiTUB) for helpful assistance and fruitful discussions during NMR characterization of the compounds, and Dr. Irene Fernández and Laura Ortiz (CCiTUB) for MS characterization. A.G. was a recipient fellow of the University of Barcelona.

\section{REFERENCES}

(1) (a) Brieke, C.; Rohrbach, F.; Gottschalk, A.; Mayer, G.; Heckel, A. Angew. Chem. Int. Ed. 2012, 51, 8446-8476. (b) Klan, P.; Solomek, T.; Bochet, C. G.; Blanc, A.; 
Givens, R.; Rubina, M.; Popik, V.; Kostikov, A.; Wirz, J. Chem. Rev. 2013, 113, 119191. (c) Hansen, M. J.; Velema, W. A.; Lerch, M. M.; Szymanski, W.; Feringa, B. L. Chem. Soc. Rev. 2015, 44, 3358-3377.

(2) (a) Noguchi, M.; Skwarczynski, M.; Prakash, H.; Hirota, S.; Kimura, T.; Hayashia, Y.; Kisoa, Y. Bioorg. Med. Chem. 2008, 16, 5389-5397. (b) Zindler, M.; Pinchuk, B.; Renn, C.; Horbert, R.; Doebber, A.; Peifer, C. ChemMedChem 2015, 10, 1335-1338. (c) Schimer, J.; Pávová, M.; Anders, M.; Pachl, P.; Šácha, P.; Cígler, P.; Weber, J.; Majer, P.; Řezáčová, P.; Kräusslich, H.-G.; Müller, B.; Konvalinka, J. Nature Commun. 2015, 6, 6461. (d) Velema, W. A.; van der Berg, J. P.; Szymanski, W.; Driessen, A. J. M.; Feringa, B. L. ACS Chem. Biol. 2014, 9, 1969-1974. (e) Olson, J. P.; Kwon, H.-B.; Takasaki, K. T.; Chiu, C. Q.; Higley, M. J.; Sabatini, B. L.; Ellis-Davies, G. C. R. J. Am. Chem. Soc. 2013, 135, 5954-5957. (f) Carling, C.-J.; Olejniczak, J.; FoucaultCollet, A.; Collet, G.; Viger, M. L.; Nguyen Huu, V. A.; Duggana, B M.; Almutairi, A. Chem. Sci. 2016, 7, 2392-2398. (g) Gorka, A. P.; Nani, R. R.; Zhu, J.; Mackem, S.; Schnermann, M. J. J. Am. Chem. Soc. 2014, 136, 14153-14159. (h) Nani, R. R.; Gorka, A. P.; Nagaya, T.; Kobayashi, H.; Schnermann, M. J. Angew. Chem. Int. Ed. 2015, 54, 13635-13638.

(3) (a) Wirkner, M.; Weis, S.; San Miguel, V.; Álvarez, M.; Gropeanu, R. A.; Salierno, M.; Sartoris, A.; Unger, R. E.; Kirkpatrick, C. J.; del Campo, A. ChemBioChem 2011, 12, 2623-2629. (b) Mosquera, J.; Sánchez, M. I.; Mascareñas, J. L.; Vázquez, M. E. Chem. Commun. 2015, 51, 5501-5504. (c) Luo, J.; Uprety, R.; Naro, Y.; Chou, C.; Nguyen, D. P.; Chin, J. W.; Deiters, A. J. Am. Chem. Soc. 2014, 136, 15551-15558. (d) Gautier, A.; Gauron, C.; Volovitch, M.; Bensimon, D.; Jullien, L.; Vriz, S. Nat. Chem. Biol. 2014, 10, 533-541. (e) Sainlos, M.; Iskenderian-Epps, W. S.; Olivier, N. B.; Choquet, D.; Imperiali, B. J. Am. Chem. Soc. 2013, 135, 4580-4583. (f) Gandioso, A.; Cano, M.; Massaguer, A.; Marchán. V. J. Org. Chem. 2016, 81, 11556-11564. (g) Steinert, H. S.; Schäfe, F.; Jonker, H. R.; Heckel, A.; Schwalbe, H. Angew. Chem. Int. Ed. 2014, 53, 1072-1075. (h) Meyer, A.; Mokhir, A. Angew. Chem. Int. Ed. 2014, 53, 12840-12843. (i) Rodrigues-Correia, A.; Knapp-Bühle, D.; Engels, J. W.; Heckel, A. Org. Lett. 2014, 16, 5128-5131.

(4) (a) Deiters, A. ChemBioChem. 2010, 11, 47-53. (b) Velema, W. A.; Szymanski, W.; Feringa, B. L. J. Am. Chem. Soc. 2014, 136, 2178-2791. (c) Szymański, W.; Beierle, J. M.; Kistemaker, H. A. V.; Velema, W. A.; Feringa, B. L. Chem. Rev. 2013, 113, 61146178. (d) Mayer, G.; Heckel, A. Angew. Chem. Int. Ed. 2006, 45, 4900-4921. 
(5) Brash, D.; Rudolph, J.; Simon, J.; Lin, A.; Mckenna, G.; Baden, H.; Halperin, A.; Ponten, J. Proc. Natl. Acad. Sci. U.S.A. 1991, 88, 10124-10128.

(6) Kalka, K.; Merk, H.; Mukhtar, H. J. Am. Acad. Dermatol. 2000, 42, 389-413.

(7) Jacques. S. L. Phys. Med. Biol. 2013, 58, R37-R61.

(8) Fournier, L.; Aujard, I.; Le Saux, T.; Maurin, S.; Beaupierre, S.; Baudin, J.-B.; Jullien, L. Chem. Eur. J. 2013, 19, 17494-17507.

(9) Hagen, V.; Dekowski, B.; Kotzur, N.; Lechler, R.; Wiesner, B.; Briand, B.; Beyermann, M. Chem. Eur. J. 2008, 14, 1621-1627.

(10) (a) Grimm, J. B.; English, B. P.; Chen, J.; Slaughter, J. P.; Zhang, Z.; Revyakin, A.; Patel, R.; Macklin, J. J.; Normanno, D.; Singer, R. H.; Lionnet, T.; Lavis, L. D. Nat. Methods 2015, 12, 244-250. (b) Grimm, J. B.; English, B. P.; Choi, H.; Muthusamy, A. K.; Mehl, B. P.; Dong, P.; Brown, T. A.; Lippincott-Schwartz, J.; Liu, Z.; Lionnet, T.; Lavis, L. D. Nat. Methods 2016, 13, 985-988. (c) Liu, X.; Qiao, Q.; Tian, W.; Liu, W.; Chen, J.; Lang, M. J.; Xu, Z. J. Am. Chem. Soc. 2016, 138, 6960-6963. (d) Singha, S.; Kim, D.; Roy, B.; Sambasivan, S.; Moon, H.; Rao, A. S.; Kim, J. Y.; Joo, T.; Park, J. W.; Rhee, Y. M.; Wang, T.; Kim, K. H.; Shin, Y. H.; Jung, J.; Ahn, K. H. Chem. Sci. 2015, 6, 4335-4342.

(11) Fournier, L.; Gauron, C.; Xu, L.; Aujard, I.; Le Saux, T.; Gagey-Eilstein, N.; Maurin, S.; Dubruille, S.; Baudin, J.-B.; Bensimon, D.; Volovitch, M.; Vriz, S.; Jullien, L. ACS Chem. Biol. 2013, 8, 1528-1536.

(12) Fonseca, A. S. C.; Soares, A. M. S.; Gonçalves, M. S. T.; Costa, S. P. G. Tetrahedron 2012, 68, 7892-7900.

(13) Kirpichenok, M. A.; Gorozhankin, S. K.; Grandberg. I. I. Chem. Heterocycl. Compd. 1988, 611-616.

(14) Yamazoe, S.; Liu, Q.; McQuade, L. E.; Deiters, A.; Chen, J. K. Angew. Chem. Int. Ed. 2014, 53, 10114-10118.

(15) (a) Li, C.; Plamont, M.-A.; Aujard, I.; Le Saux, T.; Jullien, L.; Gautier, A. Org. Biomol. Chem. 2016, 14, 9253-9261. (b) Shaya, J.; Fontaine-Vive, F.; Michel, B. Y.; Burger, A. Chem. Eur. J. 2016, 22, 10627-10637. (c) Zheng, K.; Lin, W.; Huang, W.; Guan, X.; Cheng, D.; Wang, J.-Y. J. Mater. Chem. B 2015, 3, 871-877.

(16) Jesberger, M.; Davis, T. P.; Barner, L. Synthesis 2003, 13, 1929-1958.

(17) Bordwell, F. G.; Cheng, J.-P.; Bausch, M. J.; Bares, J. E. J. Phys. Org. Chem. 1988, 1, 209-223. 
(18) Bordwell, F. G.; Drucker, G. E.; McCollum, G. J. J. Org. Chem. 1982, 47, 25042510 .

(19) Liu, X.; Cole, J. M.; Waddell, P. G.; Lin, T.-C.; Radia, J.; Zeidler, A. J. Phys. Chem. A, 2012, 116, 727-737.

(20) (a) Roubinet, B.; Renard, P.-Y.; Romieu, A. Dyes Pigments 2014, 110, 270-284.

(b) Dell'Acqua, M.; Ronda, L.; Piano, R.; Pellegrino, S.; Clerici, F.; Rossi, E.; Mozzarelli, A.; Gelmi, M. L.; Abbiati. G. J. Org. Chem. 2015, 80, 10939-10954. (c) Fajarí, Ll.; Fors, P.; Lang, K.; Nonell, S.; Trull, F. R. J. Photochem. Photobiol., A, 1996, 93, 119-128.

(21) Gandioso, A.; Palau, M.; Nin-Hill, A.; Melnyk, I.; Rovira, C.; Nonell, S.; Velasco,

D.; García-Amorós, J.; Marchán, V. ChemistryOpen, 2017, DOI: 10.1002/open.201700067.

(22) E. D. Korn, Methods in Membrane Biology Vol. 4: Biohysical Approaches, Plenum Press, New York, 1975.

(23) Kuhn, H. J.; Braslavsky, S. E.; Schmidt, R. Pure Appl. Chem. 2004, 76, 2105-2146. (24) (a) Gorka, A. P.; Nani, R. R.; Zhu, J.; Mackem, S.; Schnermann, M. J. J. Am. Chem. Soc. 2014, 136, 14153-14159. (b) Nani, R. R.; Gorka, A. P.; Nagaya, T.; Kobayashi, H.; Schnermann, M. J. Angew. Chem. Int. Ed. 2015, 54, 13635-13638.

(25) Karg, B.; Haase, L.; Funke, A.; Dickerhoff, J.; Weisz, K. Biochemistry 2016, 55, 6949-6955.

(26) Fanghaenel, E.; Engels, V. Z. Chem. 1990, 30, 364-365.

(27) Starosotnikov, A. M.; Lobach, A. V.; Shevelev, S. A. Synthesis 2005, 17, 28302832.

(28) Bonnet, B.; Campo, B.; Raveglia, L.; Riccaboni, M. U.S. Patent 20100249123 September 30, 2010

(29) Tkach, I. I.; Reznichenko, A. V.; Luk'yanets, E. A. Chem. Heterocycl. Compd. 1992, $28,872-880$. 